SEX ROLE EXPECTATIONS IN CHILDREN'S VOCATIONAL

ASPIRATIONS AND PERCEPTIONS

OF OCCUPATIONS

\author{
A Dissertation \\ Presented to \\ The School of Graduate Studies \\ Drake University
}

\author{
In Partial Fulfiliment \\ of the Requirements for the Degree \\ Doctor of Education
}

by

Mary L. Franken

August 1976 
(C) 1977

MARY L. FRANKEN

ALL RIGHTS RESERVED 


\section{SEX ROLE EXPECTATIONS IN CHILDREN'S VOCATTONAL \\ ASPIRATIONS AND PERCEPTIONS \\ OF OCCUPATIONS}

by

Mary L. Franken

Approved by Committee:

Carol A. Burden

Chairperson

Hazel Weakly

Rlchard D. Brooks

Everett E, Hadley

Stuart C. Thedeman

Earle L. Canfleld

Dean of the School of Graduate Studies

\section{9}


SEX ROLE EXPECTATIONS IN CHILDREN"S VOCATIONAL

ASPIRATIONS AND PERCEPTIONS

OF OCCUPATIONS

\author{
An abstract of a Dissertation by \\ Mary L. Franken \\ August 1976 \\ Drake University \\ Advisor: Carol A. Burden
}

The Problem. The problem of this study was to determine whether chlldren held sex role expectations in their vocational aspirations and perceptions of occupations. In addition, the differences in responses between boys and girls; between preschool, lower elementary, and upper elementary school children; and between children attending schools in two neighborhoods--one predominantly lower to lower-middle, the other middle to upper-middle class--were calculated and analyzed.

Procedure. A standardized Interview procedure was developed for use by a male and a female interviewer with 120 children who were randomly selected from three grade levels from schools representing two socioeconomic levels. Children were asked the questions, "What do you want to be when you grow up?" and "Have you any other ideas about what you might like to do?" The number (varlety) of specific occupations mentioned as first and second cholces were reported on frequency distributions. Responses were further analyzed in terms of whether the occupations named as aspirations by children were sex-typed, using Chi-square $(\mathrm{p}<.05)$ to test for independence of the varlables of sex, grade level, and socioeconomic level.

A slide-tape presentation depicting thirty actual occupational settings without a worker present was developed for use in the interviews. Children were asked who could do the work in each of the occupations--a woman, a man, or both a woman and a man. Chi-square $(\mathrm{p}<.05)$ was used to test for independence of sex, grade level, and socio-economic level as factors in sex role expectations in perceptions of occupations.

Findings. Results indicated that sex-typing in vocational aspirations was present both in the number (varlety) of occupations named as aspirations by boys and girls and in the way these occupations conformed to traditional sex roles. Boys named 29 different occupations to 25 by girls as aspirations. The number of occupations named by children increased with each higher grade level. No important differences were found in the number of occupations nominated by children from the two socioeconomic levels. Second-cholce aspirations concurred with the above trends, but of 120, 49 responses were, "I don't know." A significant relationship $(.001)$ was found between sex-typing of first-cholce occupational aspirations and the sex of the respondents. No significant differences in sextyping of aspirations were found on the varlables of grade level and socioeconomic level.

Responses to the sllde-tape series were found to be significantly related to the three varlables of sex $(.01)$, grade level $(.001)$, and 
soclo-economic level $(.05)$ of the respondents. A majority of responses of "both" Indicated that occupations were percelved as places where both a woman and a man could work. However, both boys and girls excluded women from jobs more than they excluded men from jobs. Girls, more than boys, perceived women as being able to do the work in the occupations. Sex-typing in the perceptions decreased as the grade level of the respondents increased. Responses of children from the lower to lowermiddle-class schools revealed more sex-typing than their middle to uppermiddle-class counterparts.

Conclusions. Children named a wide diversity of occupational aspirations. It appears that boys begin naming a greater variety of occupations than girls sometime between preschool and second grade. Vocational aspirations tend to be crystallized into single choices for many children, which may indicate a lack of awareness of other vocational possibilities. While children may percelve both a man and a woman as workers in an occupation, boys especially tend to choose jobs for themselves that fall within the usual stereotypes.

Recommendations. Career information experiences should extend to young children, parents, and teachers to encourage them to view occupations as places both men and women can work. Exposure to many opportunities and non-traditional role models is needed by both boys and girls, especlally those from the lower to lower-middle class. Inquiries into the effects of career education and the vocational development of children and adults should not neglect the aspect of sex role expectations. 
LIST OF TABLES ....................... vi vi CHAPTER

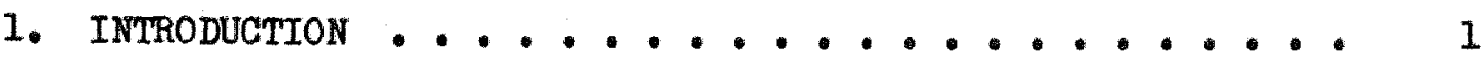
RATIONALE FOR THE STUDY . . . . . . . . . 5 STATHENT OF THE PROBLEM ................ 7 HYPOTHESES ..................... 7 ASSUMPTIONS ........................... 9 LIMTTATTONS . . . . . . . . . . . . . . . 9 DEFINITIONS ........................ 10

2. REVIEW OF RELATED LITERATURE . . . . . . . . . . 12 INTRODUCTION .................... 12 THEORETICAL CONSTRUCTS RELATED TO PSYCHOSEXUAL DEVELOPMENT ... . . . . . . . . . . . 12

Concepts in Psychosexual Developnent ....... 12 Explanations for the Process of Psychosexual Identification ..................

RELATED RESEARCH ON CHILDREN'S SEX ROLES AND SEX-TYPING . . . . . . . . . . . . . 22

Measurting Sex-Typing and Sex Role Preferences . . . 22

Parents" Influence on Sex Role Identity ...... 29

Impact of Teachers and Schools on Sex Role

Stereotypling ........................

Television's Influence on Sex-Typing ....... 44 VOCATIONAL DEVELOPNENT OF YOUNG CHILDREN AND EFTECTS OF SEX-TYPING ON THEIR ASPIRATIONS AND ATTITUDES TOWARD OCCUPATIONS ..................... 46

Vocational Development of Chlldren ....... 46 
Page

Importance of Occupational Information . . . . . 50

Occupational Interests and Aspirations...... 52

Perceptions of Roles Open to Men and Women ..... 56

EFTORTS TO COMBAT SEXISM .............. 59

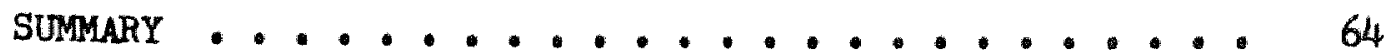

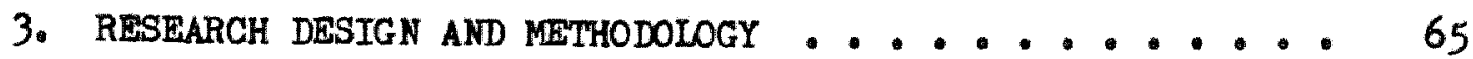

General Design .................. 65

Population and Sample ............ 66

Data and Instrumentation .......... 69

Analysis ....................... 75

4. Findings ......................... 78

SUMMARY OF FINDINGS ..................... 97

5. DISCUSSTON, CONCLUSIONS, AND RECOMAENDATIONS . . . . . 99

The Problem .................... 99

Discussion ................... 99

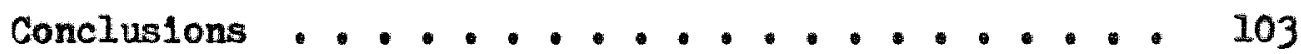

Implications and Recommendations ....... 104

BIBLIOGRAPHY ..................... 107

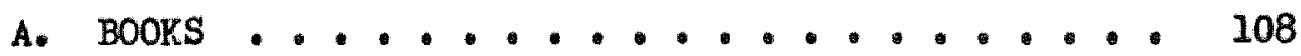

B. PERIODICALS ............... 109

C. THESES AND DISSERTATIONS ......... 114

D. DISSERTATTON ABSTRACTS .......... 114

E. ERTC REPORTS ............... 115

F. otherr SOURCES ...................... 115 


\section{APPENDICES}

A. INFORMATION NOTE FOR PARENTS ......... 116

B. INTERVIEW PROCEDURE ............ 118

C. PROCEDURES FOR SELECTING THE 30 OCCUPATIONS

REPRESEFTED IY THE STUDY ............ 121

D. SCRIPT OF THE SLIDE-TAPE PRESENTATION $\ldots . . .126$ 
LIST OF TABLES

TABLE

Page

1. Frequency Distribution of Boys' First-Cholce Occupations Named as Vocational Aspirations By Grade Lovel and Soclo-Economic Level ..................

2. Number of Different Occupations Named As Flrst-Cholce Aspirations By Boys ..................

3. Frequency Distribution of Girls' First-Cholce Occupations Named As Vocational Aspirations By Grade

Level and Soc1o-Economic Level .............

4. Number of Different Occupations Faned As FIrst-Cholce Aspirations By Girls .............. 84

5. Comparisons of the Numbers of Different Occupations Named As Flrst-Cholce Asplrations By Children Attending Tro Socio-Economic Level Schools .......

6. Frequency Distribution of Boys' Second-Cholce Occupations Naned As Vocational Asplrations By Grade Level and Socio-Economic Level ............

7. Number of Different Occupations Named As Second-Cholce Aspirations By Boys ..................

8. Frequency Distribution of Girls' Second-Cholce Occupations Named As Vocational Aspirations By Grade Level and Socio-Economic Level .............

9. Number of Dfferent Occupations Named As Second-Cholce Aspirations By Girls ..................

10. Comparisons of the Numbers of Different Occupations Named As Second-Cholce Aspirations By Children Attending Two Socio-Economic Level Schools .......

11. Contingency Table Showing Relationship of Sex-Typing in PIIst-Cholce Aspirations and Sex of Respondents . ...

12. Contingency Table Showing Helationship of Sex-Typing in First-Choice Asplrations and Grede Level of Respondents ........................

13. Contingency Table Shoulng Relationship of Sex-Typing in First-Cholce Aspirations and Socto-Economic Level of Respondents ................... 
v11

TABLE

Page

14. Contingency Table Showing Relationship of Sex Role Perceptions of 30 Occupations and Sex of

Respondents............................. 94

15. Contingency Table Showing Relationsh1p of Sex Hole

Perceptions of 30 Occupations and Grade Level

of Respondents . . . . . . . . . . 95

16. Contingency Table Showing Relationship of Sex Role

Perceptions of 30 Occupations and Socio-Economic

Level of Respondents ................. 96

17. Sixty Occupations from the U.S. Offlce of Education

Clusters Rated by 10 Judges into Categorles of

Traditionally Male, Traditionally Female, and

Neutral ....................... 123

18. Occupations Selected for the Study from the 15 U.S.

Office of Education Career Clusters with Proportion

of Rater Agreement for Assignment to Male, Fenale,

or Neutral Category by 10 Raters . . . . . . . . 124 
Chapter 1

INTRODUCTION

Career education and greater awareness of sexism in schools and soclety are two recent trends whlch have influenced the education of young children. The differential socialization that males and females recelve from birth has been related by many to the inequality of opportunities which have existed between the two sexes in education, employment, and in many other aspects of soclety. Weltzman asserts that "the socialization process shapes the sex roles that men and women come to accept as self-evident. " 1

Over the past two decades theorists in occupational psychology have placed increased emphasis on regarding vocational choice as a developmental process and as an implementation of a person's selfconcept. Theorists have related early childhood expertences to vocational choice. Ginzberg included a fantasy perlod in his theory in which he belleved children under age eleven were governed by the wish to be an adult. ${ }^{2}$ Roe related parental attitudes and handling of their children to the children's need satisfactions and to their orientation to persons later in 11fe. Roe saw these relationships as being very

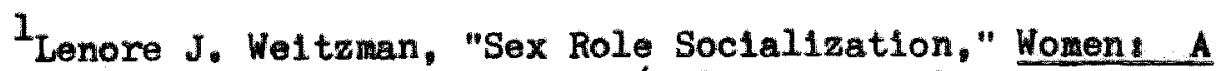
Feminist Perspective, od. Jo Freeman (Palo Alto, Callfornisi Mayfleld. 1975). p. 105 .

2Donald Super, "A Theory of Vocational Development," Amerlcan Psycholog1st, VIII (May, 1953), 186.
} 
influential on occupational choice. ${ }^{1}$ Childhood experiences play a major role in the theory of Holland. ${ }^{2}$ Super's view can be summarlzed as follows:

The process of vocational development is essentially that of the developing and implementing a self concept, it is a compromise process in which the self concept is a product of the interaction of Inherited aptitudes, neural and endocrine make-up, opportunity to play various roles, and evaluations of the extent to which the results of role playlng meet with the approval of superiors and fellows. 3

Hoppock points out that between kindergarten and grade 6 meny chlldren announce their vocational intentions. Adults expect that early choices of children will change, and they usually do. Hoppock asserts,

No one wants to urge or even encourage childiren to make dectsive vocational cholces before such choices must or should be made, but this does not mean that ogcupational cholces in early chlldhood should be Ignored. 4

However, Kirchner and Vondracek assert that,

The view that vocational development encompasses the entire life span and entalls progression through identifiable stages has been accompanied by scant research on vocational behavior in the preschool years. 5

In a study which they conducted, they found that aspects of rocational development followed an orderly pattern in early childhood. Also, even

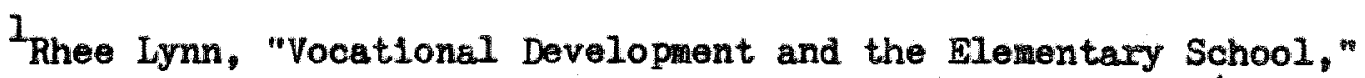
Developlng Careers in the Elementary School, ed. Norman Gysbers (Columbus, Ohio: Charles E. Merr111, 1973), p. 44.

${ }^{2}$ Lynn, p. $46 . \quad 3$ Super, p. 189.

4 Robert Hoppock, Occupational Information (New York, MoGrawH111, 1967), p. 348 .

5 El1zabeth P. KIrchner and Sarah I. Vondracek, What Do You Want to Be When You Grow Up? Vocational Cholces in Children Aged Three to S1X, U.S. Educational Resources Information Center, ERIC Document ED 076 244, March, 1973, p. 1. 
in the preschool years, significant sex and race differences were evident in vocational behavior. Their findings suggest that a major aspect of vocational development in early childhood is projection into one's future role as an adult, specifically an adult Identifled vocationally. Their age-related findings suggest an important stage--mastery of the task of projecting oneself as one day achieving adult status-as a precursor to Havighurst's first step in vocational development, occurring at age five. which he calls identification with a worker. 1

Efforts in career education to provide for more vocational flexIbility in a world of rapid vocational change, besides ignoring the importance of the preschool years, also have not recognized "the serfousness of the vocational miseducation of girls." 2 Mitohell believes that attitudes limiting career opportunities, including stereotypes of sex roles, are rooted deep in early childhood. 3 As early as the upper elementary grades, many girls indicate they believe the occupational options open to them are restricted to four teacher, nurse, secretary. and mother. 4

Weltzman discusses studies which reveal the differential social1zation, treatment and expectations that male and female children recelve from parents, teachers, books and the medis. GIrls are taught to have

$1_{\text {Kirchner and Vondracek, p. } 5 .}$

2Edna M1tohe11, "What About Career Education for Girls?" Educat1onal Leaderghip, XXX (December, 1972), 233.

3 Mitche11, pe 233.

4 Myra Sadker, "Are You Guilty of Teaching Sex Bias?" Instructor. LXXXII (August, 1972), 80. 
low aspirations, she believes, because so few opportunities are portrayed as avallable to them. A study she conducted analyzing plcture books revealed the girls' occupational world as consisting primarily of glamour and service. ${ }^{1}$ Hartley found men in children's eyes to be active and intelligent while women were seen as a rather tired and unintelligent group. 2 Schlossberg and Goodman conclude that males and females are viewed differently from birth, often in a way suggesting inferlority for women. 3

The preceding authors assert that girls are taught an expressive, submissive, supporting role while boys are taught an instrumental, domin ant, achieving role. If this is true, these patterns, which relate closely to self image, are well underway in preschool and elementary school years and are probably reflected in children's stated asplrations and in perceptions of whether an occupation is open to both sexes.

The tendency to socialize women for expressive rather than instrumental competence has been used as an explanation for the fact that women continue to hold a small percentage of positions in higher professions and fewer leadership roles. Horner belleves another factor is that women have a "motive to avold success." 4 By this she means that they have a

$$
\text { Weitzman, p. 111. 2We1tzman, p. } 112 .
$$

${ }^{3}$ Nancy K. Schlossberg and Jane Goodman, "A Woman's Place: Children's Sex Stereotyping of Occupations," Vocational Guidance Quarterly, XX (1972), 266-270.

4 Matina Horner, "The Motive to Avold Success and Changing Aspirations of College Women," Readings on the Psychologx of Women, ed. Judith Bardwick (New Yorki Harper and Row, 1972), p. 62. 
tendency to become anxious about "achleving" because they anticipate or expect negative consequences because of success. Therefore, the ways children are soclalized, beginning at birth, have important ramifications In the development of self concept, achievement orientation, and aspirations for the future.

If an Individual's stated aspirations and perceptions of occupations are viewed as extensions of his/her value system about the world of work, then these can be considered a part of an individual's total value system and, as such, interrelated with self concept, forming a part of the phenomenal self described by Snygg and Combs. 1 Thus it would be expected that the concepts of self held by an Individual would Influence and be influenced by his/her role perception. Studying sex role perceptions of children is helpful in understanding their views about self and the world of work.

\section{RATIONALE FOR THE STUDY}

Researchers in recent years have investigated children's knowledge, aspirations, and perceptions of the world of work. The present study attempted to alleviate some of the criticlsms about methodology of previous research. In addition, preschool children were included, making 1t possible to compare responses of preschoolers with elementary school childron.

Fulton developed a comprehensive instrument to study young

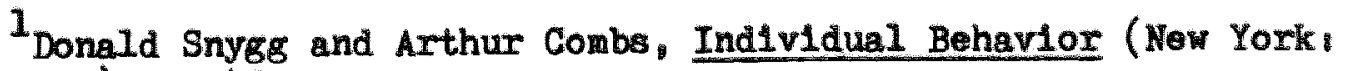
Harper, 1959), p. 43 . 
children's knowledge and att1tudes about work and occupations. ${ }^{1}$ But her Instrument, like others before 1t, perpetuated stereotypes because male figures dominated the drawings presented of the occupational settings. She also neglected to report differences between boys and girls in her analyses. This was espectally crucial on the scale which sought to compare perceptions of the sex of the worker by children of different ages.

In a recent study, Schlossberg and Goodman used twelve drawings to assess sex-typing of occupations by kindergartners and sixth-grade children. 2 The present study used thirty occupational settings, permitting a wider range of perceptions to be studied. A slide-tape format used photographs of actual occupational settings, lending groater realism. Slides did not show workers present since this could influence children to sex-type an occupation. The methodology tended to eliminate and/or control sex bias in the interview procedure and instrument development. which was often not adequately accounted for in previous rasearch studies. Since much of the earller research was conducted before the women's movement and career education programs had their lmpact on schools and children, the present study permitted a timely look at current perceptions and sex role expectations of occupations held by young children. Unllke other studies which forced children to choose between male and fomale in their responses, children were given the option to give "both man and woman" as a response.

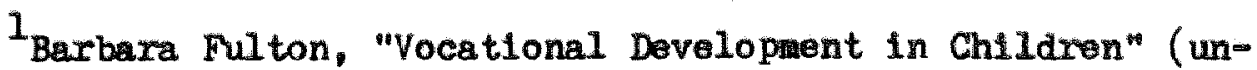
published Doctoral dissertation, University of Missourt, Colunbia, 1971).

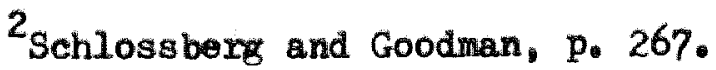


The findings of this study contribute to the growing body of research about vocational development and interests of children and about the effects of sex-typing and sex role expectations on vocational behavior. These are important areas if boys and girls are to be helped to realize their potentials and if they are to perceive a wide varlety of vocational choices as being open to them.

\section{STATEMEETT OF THE PROBLEM}

The problem was to determine whether children held sex role expectations in their stated vocational aspirations and in perceptions of occupations. In addition, the differences in responses between boys and girls, between preschool, lower elementary, and upper elementary children; and between children attending schools in two neighborhoods--one predomInantly lower to lower-middle class, the other middle to upper-middle class-were calculated and analyzed.

\section{HYPOTHESES}

Based on the review of related literature, several questions and hypotheses were generated for investigation. It was anticlpated that as the ages of the children increased, the total number of occupations named as vocational aspirations would increase for both boys and for girls. It was further hypothesized that sex differences in sex role expectations, both in stated vocational aspirations and in perceptions of occupations, would be present at each of the three levels included in the study. It was anticipated that boys would name a greater number of occupations as aspirations than girls at each age level. It was also expected that 
occupations named as aspirations by boys and girls would be sex-typed. Both boys and girls were predicted to view occupations along traditional stereotypic roles rather than as neutral places where both females and males could work. It was expected that both boys and girls would exclude women from "men's" jobs more than they exclude men from "women's" jobs and that this would be more apparent in the girls" responses than in the boys' responses. It was further hypothesized that responses from children attending schools in a lower to lowermiddle class neighborhood would reverl more sex-typing than the children in the middle to upper-middle income neighborhood schools.

Three questions were posed to investigate the differences in number (varlety) of occupations named as aspirations by the subjects in the study:

1. Do boys and girls differ in the number (variety) of occupations named as aspirations?

2. Do children at different grade levels differ in the number (variety) of occupations named as aspirations?

3. Do children of different socio-economic levels differ in the number (variety) of occupations named as aspirations?

The following six null hypotheses were used to test the predictions about sex role expectations in chlldren's vocational aspirations and perceptions of occupations

1. Sex-typing of children's vocational aspirations is independent of the sex of the respondents.

2. Sex-typing of children's vocationsl aspirations is independent of the grade level of the respondents. 
3. Sex-typing of children's vocational asplrations is independent of the socio-economic level of the respondents.

4. Sex role expectations in children's perceptions of occupations are Independent of the sex of the respondents.

5. Sex role expectations in children's perceptions of occupatione are independent of the grade level of the respondents.

6. Sex role expectations in children's perceptions of occupations are independent of the socio-economic level of the respondents.

\section{ASSUMPTIONS}

For the purposes of this study the assumption was made that boys and girls as young as age four have some ideas about possible vocational selections. The assumption was also made that current interests as well as experiences in and out of the home and school might have an effect on stated aspirations and perceptions of occupations. Finally, it was assumed that the chtldren in the sample would be able to express their aspirations and respond to the slide-tape presentation in a one-to-one Interview situation.

\section{LIMITATIONS}

Selection of occupations that were included in the slide-tape presentation was 1imited by avaliability of settings for photographing. although still plctures were used in several instances and made into slides. The cholces were also 11 mited to occupations with which preschool children could make an association. Findings of the study may only be applicable to populations siallar to the sample represented in the study. 
DEFINITIONS

The following definitions were used in the study

1. Career education. "A sequence of planned educational activities designed to develop positive student attitudes, values, knowledges, and skills toward self and the world of work that will contribute to personal fulfillment in present and future life opportunities as well as economic independence." 1

2. Career. "Work that can begin to satisfy both individual and soctal needs." 2

3. Occupation. Work that is performed as a task with some rewards based on the personal pride of doing a job well with a sense of social participation. ${ }^{3}$

4. Stereotypes are "assumed differences, soclal conventions or norms, learned behavior, attitudes, and expectations " 4

5. Role. A cluster of socially or culturally defined expectations that individuals in a given situation are expected to fulfili. 5

6. Sex role. The learned behaviors or characteristics that

${ }^{1}$ State of Iowa, Department of Public Instruction, Models for Career Education in Iowa-Implementing Career Education in the School Curriculum (Des Molnes, Iowa: Department of Public Instruction, 1974). pp. 10-11.

${ }^{2}$ Samuel H. Osipow, Theorles of Career Development (New York: Appleton-Century-Crofts, 1973), p. 266.

3osipow, p. 266.

4 Florence Howe, "Sexual Stereotypes Start Early," Saturday Revlev. LIV (October, 1971), 77.

5 Janet Saltzman Chafetz, Masculine, Feminine, or Human? (Itasca, Illinols, F. E. Peacock, 1974), p. 3. 
have been defined by society as either "masculine" or "feminine."1

7. Traditional occupation or role is what is classified as "feminine" or "masculine" according to the major sex represented in that occupation. 2

8. Sex-typing. Associating an activity or perception with only one sex.

9. Aspiration. "The act of seeking to attain something high ox great." 3

IChafetz, p. 3.

$2_{\text {Sehlossberg and Goodman, p. } 267 .}$

Webster's New Colleplate Detionary (Springfleld, Massachusetts: G. and C. Merrian Co. 1956), p. 53. 
Chapter 2

REVIEW OF RELATED LITERATURE

\section{INTRODUCTION}

Research findings and a summary of the related Ilterature w11 be presented around the following toptcs,

1. Theoretical constructs related to psychosexual development.

2. Related research on children's sex roles and sex-typing.

3. Vocational development of young children and effects of sextyping on their aspirations and attitudes toward occupations.

4. Efforts to combat sexism.

THEORETICAL CONBTRUCTS RELATED TO PSYGHOSEXUAL DEVELOPMENT

Concepts in Psychosexual Development

One of the most stable aspects of soclallzation is the learning of sex-approprlate behavior. Acquiring a sex role is a part of a person's psychosexual development. McCandless and Bvans refer to psycho= sexual development as both a product-a set of responses that characterize a person's social and sexual relationships with others-and a process-w the way in which one acquires psychosexual characteristics. ${ }^{1}$ They define psychosexual dovelopment as 8

the psychological ways in which one adjusts to his (her) ${ }^{2}$ blologlcally defined sex role and learns his (her) sexuality

1Boyd R. McCandless and E1IIs D. Evans, Children and Youth Psychosocial Development (Hinsdale, Illinols: Dryden Press, 1973). p. 229.

Words in parentheses added by this writer. 
in the broadest social sense of the term "sexuality." At maturity, such development can be measured in terms of how one behaves with reference to his (her) gender. 1

Psychologists discuss several important concepts in describing the process of psychosexual development. Sex-typing is the acquisition of behavior associated with male or female sex roles, moving through phases of discrimination, generalization, and performance. ${ }^{2}$ Sex-typed behaviors typically elicit different rewards for one sex than for the other. According to soctal learning theory, the acquisition and performance of sex-typed behavior can be described using the same learning principles as other aspects of a person's behavior. ${ }^{3}$

Sex role identification is the degree to which an individual regards himself/herself as masculine or feminine, though there is little empirical information that deals with the mode of establishment of a child's sex role identity. Kagan speculates that the major determinants of sex role identity for a young child include perceptions of similarity to parents and the degree to which a child adopts the games and learns the skills that are traditionally encouraged for his/her sex. ${ }^{4}$ His research using game and toy choices as an index of sex-typed behavior

\section{TMcCandless and Evans, p. 229.}

Walter Mischel, "A Social Learning View of Sex Differences in Behavior," The Development of Sex Differences, ed. Eleanor Maccoby (Stanford, Stanford University Press, 1966), p. 57.

3 Mischel, p. 56.

4 Jerome Kagan, "Acquisition and Significance of Sex-Typing and Sex Role Identity," Review of Child Development Research, Vol. I, eds. M. L. Hoffman and L. W. Hoffman (New York! Russell Sage Foundation, 1964), pp. $137-168$. 
revealed boys as having an increasing preference with age for sexappropriate games. For girls, however, Kagan found that many girls between ages 3 and 10 showed a strong preference for masculine games and objects. 1

Contrasting findings were reported by Loof $t^{2}$ and Kirchner and Vondracek ${ }^{3}$ who found that girls leamed earlier than boys that certain adult statuses were not open to theil and named more strictly female related preferences.

A third concept, sex role standard, summarizes the culturally approved characteristics for males and females. ${ }^{4}$ Characteristics that define male and female have been divided into physical attributes and overt behaviors. Kagan sumnarlzes some of the sex role standards sanctioned by the culture. Desirable qualitles that have been stressed for girls included being pretty, small, hairless and having an attractive face, and moderate-sized breasts. Valued characteristics in boys have included being tall, muscular, with body hair. The standard for girls' behavior was to inhibit verbal and physical aggression; to encourage dependency, passivity, and conformity; and to regard afflliative and nurturant behaviors as appropriate. The behavior standard for boys

\section{IKagan, P. 140 .}

W. R. Looft, "Sex Differences in the Bxpression of Vocational Aspirations by Elementary School Children," Developmental Psychology, V (1971), 366.

Blizabeth P. Kirchner and Sarah I. Vondracek, What Do You Want te Be then You Gron Up? U.S., Educational Resources Information Center, ERIC Document ED 076244 , March, 1973.

4 Kagan, p. 138. 
included license and encouragement to express aggression and to develop gross motor and mechanical skills. ${ }^{1}$

One further concept requires clarification. Howe defines sexual stereotypes as "assumed differences, social conventions or norms, learned behavior, attitudes and expectations."2 Sexual stereotypes are not to be identified with sexual or innate differences, Howe states, "There is still no 'hard' scientific evidence of innate sexual differences, though there are new experiments in process . . . for human beings, at least social factors and pressures are more important than psychological ones." 3 Sex role stereotypes tend to be global, semantically vague, and difficult to examine empirically. They are also widely generalized across diverse situations and remarkably persistent in the thinking of the individuals throughout society.

McCandless and Evans assert that stereotypes clearly affect behavior and are related to the concept of expectancy, particularly expectancies held for a person by others. Differential expectancles are held for children by their parents as early as infancy and thereafter influence the course of psychosexual development. 4

The impact of social stereotypes has received much recent attention from feminists and proponents of the women's movement. Studies

TKagan, p. 139 .

2 Florence Howe, "Sexual Stereotypes Start Early," Saturday Revlew, LIV (October, 1971), 77

Howe, p. 77

4 McCandless and Evans, p. 231. 
confirm that girls have been socialized for an expressive role while boys have learned an instrumental role. As early as 1964 Kagan discussed the implications of the fact that the proportion of women in professional and technical occupations had actually decreased during the last several decades. He suggested that the increasing number of working women did not necessarily reflect a growing tendency for women to assume an instrumental role. Rather, it could reflect the nurturant attitude toward the family since the motivation to work outside the home may be to increase the family income.

Tyler discussed the developmental research of the 1950's and 1960 's and the persistent questions, "Why have women's achievements falled to match those of men? Why are there so few outstanding female artists, scientists, and statesmen?" ${ }^{2}$ She stressed the need for further research to determine when and how sex roles are learned and the factors which influence this complex learning process. ${ }^{3}$

\section{Explanations for the Process of Psychosexual Identification}

Four different theoretical sequences have been used to explain the process of psychosexual identification. Freud's classical psycho= analytic is one theoretical model that has affected theorists of development and personality. He saw two processes in identification-first, a

$$
\text { Kagan, p. } 144 \text {. }
$$

2Leona Tyler, "Individual Differences s Sex Differences," Intexnational Encrclopedia of the Soclal Sciences, Vol. VII, ed. David Sills (New York: Macmillan and the Free Press, 1968), p. 208.

3yler, p. 212 . 
strong dependency and love relation with the mother and her children, both boys and girls, beginning in infancy. This is the only process or at least the major one for girls. The girl develops her conscience or super-ego to please her mother as her mother's attention is diverted from the growing child. Boys are thought to seek to recapture the mother and to have sexual fantasies about her. The second factor-m threat--is the cause for the son to make a defensive identification with his father to avoid castration. Freud postulated a weaker super-ego for women than for men because of the less harsh process which girls go through in identification. ${ }^{1}$ This theory has entered into social stereotypes about women and is vigorously rejected by women's groups today. ${ }^{2}$

The Freudian model is perpetuated by some psychiatrists who see women in a submissive role. Welsstein quotes psychologist Bruno Bettelheim:

We must start with the realization that, as much as women want to be good scientists or engineers, they want first and foremost to be womanly companions of men and to be mothers. 3

Weisstein also clted a biased view of women described by psychiatrist Joseph Rheingold:

- When women grow up without dread of their biological functions and whout subversion by feminist doctrine and - - enter upon motherhood with a sense of fulfiliment and altruistic sentiment, we shall attain the goal of a good life and a secure world in which to live $1 t_{0}{ }^{4}$

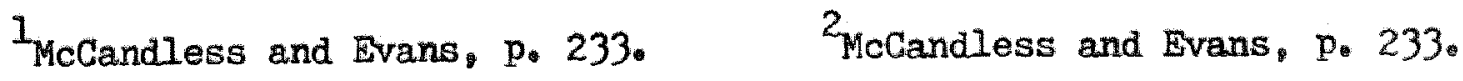

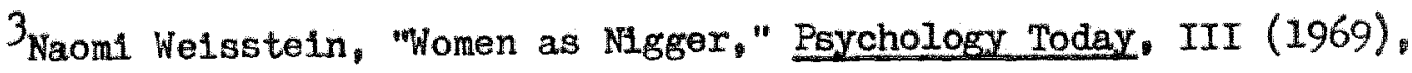
20. 4 Weisstein, p. 20.
} 
Cognitive development theory is a second way of looking at psychosexual development. Cognitive theorists emphasize the 1 dea that commonly held soclal stereotypes define what is masculine and feminine for almost all members of a culture. Consistent with stage theories of development, this view holds that "the natural development of a child's body and role concepts determines the formation of his sex-role attitudes and identifications."1 This theory stresses universal experiences and views personality as a reflection of age--with typical motives and world views-rather than a reflection of stable, individual personality traits. Lawrence Kohlberg, major proponent of this theory, maintains that the child first develops the 1dea of himself as a boy or girl, which apparently happens by age two or three, and then perceives those certain attitudes and behaviors that are categorized by that sex type. Last of all, the child begins to adopt those traits associated with that sex, and the labels become a significant part of a child's self-concept. This theory draws upon Plaget's concepts of mental development through experience.

Montemayor discussed the research findings from his study of six to elght-year-olds in terms of Kohlberg's theory. He compared subjects scoring high and low on the IT Scale for Children (ITSC) with another game measure he devised. Montemayor suggested that a child's conception of male and female undergoes considerable change with time

1Lawrence Kohlberg, "A Cognitive-Developmental Analysis of Children's Sex-hole Concepts and Att1tudes," The Development of Sex Differences, ed. Eleanor Maccoby (Stanford Stanford UnIversity Press. 1966), p. 155. 
and should not be expected to have the sane sex role standard as adults. He cited the need for more research to separate the cognitive and motivational factors in sex-typing and questioned the sensitivity of the ITSC as an instrument for the measurement of either differences between or within sexes. 1

A third theory of psychosexual identification-ocombination theory-uses interpretations from psychoanalytic and cognitive based concepts. McCandless and Evans quote Lymn,

Parental 1dentification is the internalization of personality characteristics of a given parent and .. unconscious reactions similar to those of the parent... (while) sex role identification refers to the internalization of aspects of the role considered appropriate to a given sex and to the unconsclous reactions characterlstic of that role. 2

According to this view, a child could concelvably identify with a cross-sex parent or not identify at all with a parent, yet identify with the appropriate sex role. However, all the following conditions must be considered in the development of both parental and sex role identification:

1) Parental preference

2) Sex-role preference

3) Percelved parental sinilartty

4) Perceived sex-role similarity

5) Parental behavior adoption

6) Sex -rolo adoption. 3

For girls the rationale is that parental and sex role identifica-

$1_{\text {Raymond Montemayor. Children's Performance on and Attraction }}$ to an Activity as a Function of Masculine, Feminine, or Neutral Labels on Sex-Role Preference, U.S. Educational Resources Information Center, ERIC Doctment ED 068 875. 1973.

2McCandless and Evans, p. 234. 3 McCandless and Evans, p. 234. 
tion are lessons to be learned, while for boys, they are problems to be solved. Implications about personality have been drawn--conclusions that girls and women would be inferior in problem-solving skills and would have weaker super-egos. The converse would be viewed for boys and men who, while solving their problem of 1dentifying with males also learn the instrumental masculine social role and would at the same time become superior to girls and women in problem-solving and conscience development. These contentions have not been substantiated through research.

A final theory of psychosexual development is a soctal learning theory based on the princlples of modeling and reinforcement. According to Jandt, "Social learning theorists belleve that children acquire appropriate sex-role behaviors through the active teaching by parents, peers, and teachers and through imitating the behaviors of these influential persons." 1 Rewards and punishments are adminlstered for appropriate and inapproprlate behavior, according to culturally approved standards. Both subtle and overt processes occur in teaching this sociallzation process.

The social learning view of sex-typing has been supported by many research findings, Studies by Etaugh, Collins and Gerson, ${ }^{2}$ Gold and St. Ange, ${ }^{3}$ Kagan, ${ }^{4}$ and many others lend support to the belief that

$1_{\text {Fred E. Jandt, The Process of Interpersonal Communication }}$ (San Franciscos Canfleld Press, 1976), p. 105.

${ }^{2}$ Claire Etaugh, Gene Collins, and Arlene Gerson, "Reinforcement of Sex-Typed Behaviors of Two-Year-0id Children in a Nursery School Setting," Developmental Psychology, XI (1975), 255.

3 Alice R. Gold and Carol St. Ange, "Development of Sex Role Stereotypes in Black and White Elementary School Girls, "Developmental Psychology, X (1974). 461 .

4 Jerome Kagan, "The Ch1ld"g Sex Role Classiflcation of Sohool Objects," Child Development, XXXV (1964), 1051-1056. 
children's adoption of sex-typed cholces of objects, games, and toys

seem to be based on the social learning theory. Howe concludes

Chlldren learn sexual stereotypes at an early age, and by the time they get to fifth grade, it may be terribly difficult, perhaps hardly possible by traditional means, to change their attitudes about sex roles-whether they are wale or female. 1

Regardless of the process occurring in a child's identity develop ment, a child does 1dentify with some model or role. Seven generalizations in the form of tentative conclusions emerged from the research on identification and sex-typing. McCandless and Evans summarize conclusions in approximately the order of the firmess of the findings:

1) Both an awareness and a manifestation of "sexappropriate" behavior are apparent among children as early as age 3, and most certainly by nearly all children by age 5. In fact some authorities have suggested that the first two years of 1 ife represent a "critical period" in sex-typing.

2) Boys are more clearly affected by father absence, the earlier in a boy's 11 fe $\mathrm{h} / \mathrm{s}$ father leaves the home, the more 11kely will the boy's development be affected adversely. Girls with fathers present are more evenly balanced cognitively. On the whole, for both sexes, but more clearly for boys, soclal adjustment is better when fathers are in the hone.

3) Children and young people with appropriate sex-role typing and Identification seem on the whole to have better self concepts than those with less appropriate sex-typing.

4) Parental warmth and power are both important in determining parental identification. It seens ideal for children's psychosexual development for the parent of the same sex to possess qualities of both warmth and power, although the evidence is clearer for boys than for girls. Boys Identify maximally (and here the evidence is clear) with fathers who 
are loving toward them and who are also powerful in the sense that they exert leadership roles in their marrlage and famlly situations.

5) Girls whose mothers 1dentify with them (who are informed about their daughters' interests) identify more closely with their mothers than girls whose mothers are unaware of their interests.

6) No really solid evidence has accumulated to indicate that there are general traits of aggressiveness or dependency. Boys, girls, young men, and young women are more reluctant to aggress toward females than toward males, when the aggression takes the form of administering electric shock.

7) Appropriate sex-role behaviors are more consistent than inappropriate sex-role behaviors. ${ }^{1}$

Weltzman provides a summary of how the socialization of sex

roles progress during the preschool years. First, simple behavioral reinforcement occurs, beginning at birth. Later the child learns the following:

1) to distinguish between men and women and between boys and girls, and to know what kinds of behavior are characteristic of each;

2) to express appropriate sex-role preferences for himself or herself;

3) and to behave in accordance with sex-role standards. 2

RELATED RESEARCH ON CHILDREN"S SEX ROLES AND SEX-TYPING

\section{Measuring Sex-Typing and Sex Role Preferences}

Varlous experimental techniques for finding out what young

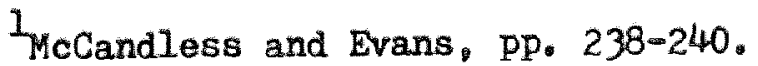

${ }^{2}$ Lenore J. Weltzman, "Sex Role Soctalization," Women, A Feminist Perspective, ed. Jo Freeman (Palo Alto, California Mayfield Publishing Co., 1975), p. 109. 
children consider the proper sex roles to be and how they relate themselves to them have been devised. These techniques include standardized doll-play situations, the telling of storles about pictures, the choice of toys or activities about plctures, and the cholce of toys or activities for a hypothetical boy or girl.

Brown, who defined sex role preference as "behavior associated with one sex or the other that the individual would like to adopt or that he perceives as the preferred or more desirable behavior, "1 developed an instrument called the IT Scale for Children in 1956 which has been widely used since then as a measure of sex role preference. The scale consists of thirty-six plcture cards depicting various objects, figures, and activities commonly assoclated with masculine or feminine roles. A child-figure drawing, referred to as "It," unstructured as to sex, is used by having each child make cholces for "It." The score range of the ITSC is from zero, an exclusively feminine score, to elghty-four, an exclusively masculine score. Brom defended the operational validity of the scale primarfly on the assumption that what is socially regarded as, and actually assoclated with, masculine or feminine behavior is an adequate basis for determining sex role patterns. A test-retest rella bll1ty for boys was .71, and for girls, .84. However, Brown himself questloned how wuch the ITSC taps role preference as much as it does role ldentification. 2

In his orlginal study using the ITSC, Brown tested 78 male and

${ }^{1}$ Dantel G. Brown, "Sex-Role Preference in Young Children," Psycholog1cal Monographs, LXX (14, Whole No. 421, 1956), 3 .

$2_{\text {Brown, p. } 8 .}$ 
68 female middle-class kindergarten children. His findings showed large and significant differences between boys and girls. A number of children In both groups showed a mixed preference patterm. Boys showed a signiflcantly greater preference for the masculine role than girls did for the feminine role. Brown felt the results were evidence for the assumption of greater prestige and value in the male compared to the female role in young children. 1

Hartop and Zook extended Brown's work with the ITSC by using it with three and four-year-olds with three different sets of verbal instructions being employed. They found four-year-old girls scored more feminine than three-year-old girls, four-year-old boys more masculine than three-year-old boys at a borderline level of signiflcance girls responded more with feminine scores when "It" was called a girl; and boys responded with more masculine scores when the flgure was called by the subject's own name than when the figure was called "It." Their findings imply that the acquisition of sex role preferences by the male is a less complicated developmental process than for the female. The findings also suggest that the ITSC is highly sensitive to variation In the instructions given to the subjects. 2

The major criticisw leveled against the instrument is that "It" actually looks like a boy, rather than a nouter figure. Therefore many children make choices for boys rather than projecting their own cholces

\section{$1_{\text {Brown, p. } 18 .}$}

2W. W. Hartop and E. A. Zook, "Sex Role Preference in Threeand Four-Year 0ld Children," Journal of Consulting Psycholosy, XXIV (1960), 420-426. 
onto "It." There is considerable evidence to support such a criticism. ${ }^{1}$ Lansky and McKay eliminated the possible masculine stimulus effect of "It" by testing kindergarten children with the figure concealed in an envelope. They found that boys were more varlable than girls in this situation. They also point out the need to devise new measures of sex role identification and preferences because the bipolar assumption between masculinity and femininity is untenable. ${ }^{2}$

Montemayor, who discussed Kohlberg "s cognitive theory, disputed the conclusion frequently cited by empirical evidence based on the ITSC that boys have a stronger preference for the male role than girls do for the female role. He gave the ITSC to 263 six to eight-year-old children and chose the top and bottom thirty subjects of each sex for the study to play a game called "Mr. Munchy." He concluded that a mismatch of preference, as indicated on the ITSC, does not necessarily imply a lower motivation to act consistent with the accepted standard but rather could mean that the child has not learned the standard or has learned it in a different form. 3

The ITSC was also used by Hall and Kelth in their study of the relationship between sex role patterns in childhood and the social status of the family to which they belong. Subjects were 88 children. aged 8 to 10. Boys of the lower socio-economic class demonstrated more

$1_{\text {Hartop and Zook, pp. } 420-426 .}$

${ }^{2}$ L. M. Lansky and G. Mckay, "Sex Role Preference of Kindergarten Boys and Girls, Some Contradietory Results," Psychological Reports, XIII (1963), 421.

Montemayor, p. 14. 
clearly masculine sex role preference than boys of the upper class. A sililar trend for girls and femininity scores wes found, but the difference was not as significant. Boys of both classes revealed more distinctly wasculine sex role preference than girls evidenced feminine sex role preference. ${ }^{1}$

Thompson and MeCandless further studied the effects of instructions used with the ITSC and added to the normative data for the scale for lower-class Negro and White children. Their sample numbered seventytwo lower-class prekindergarten children. They found race to be an important varlable in the responses to the test-many White girls responded to masculine cues in the "It" flgure, however, this was not true anong Negro girls. Lower-class Negro boys showed greater preference for the feminine role. Thompson and McCandless concluded,

The relationship of the ITSC Scores and the teacher ratings of the children's behavior supported the hypothesis that the development of sex role preference precedes the development of sex role adoption, suggesting that the rate of development may be faster among White boys. 2

A study to assess the timing and sequence of sex role development and to investigate the relationships among the three aspects of such development was done by Ward. Measures of preference, adoption, and identification were used with the 16 boys and 16 girls in the study

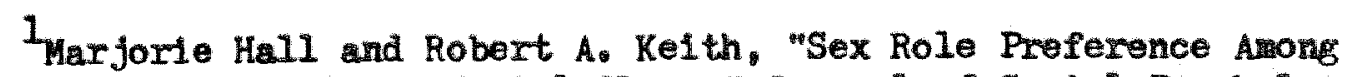
Ch1ldren of Upper and Lower Social Class," Journal of Social Psycholagy, LXII (1964), 101-110.

2 Norman L. Thompson and Boyd R. McCandless, "IT Score Variations by Instructional Style," Chtld Developient, XLI (1970), 425. 
who were enrolled in kindergarten through grade two. The ITSC was used as the measure of sex role preference. Results tentatively suggest that sex role preference is established for both sexes by the age of five, sex role identification occurs earlier for girls than for boys, role preference precedes role adoption for both sexes, role adoption and role Identification occur together anong firls but in sequence among boys, and that the three measures of sex role development were independent. 1 This writer would like to point out that the small sample size of thirtytwo should be taken into account when considering the conclusions suggested by Ward.

Biller used a modifled ITSC to measure sex role orlentation of thirty-four kindergarten boys, matched by pair on the varlable of fatherabsent and father-present. All mothers of kindergarten boys in this school were sent questlonnaires to assess father availab1lity and maternal encouragement of masculine behavior. A game preference task was also used th the boys. Biller concluded,

Compared to fatherabsent boys, father-present boys vere found to be much more masculine in projective sex-role identification and slightly more masculine in game preference but were not significantly different in terms of a rating scale measure of overt masculinity. For father absent boys, but not for father-prosent boys, degree of maternal encouragenent of masculine behavior was related to masculinity of game preference and the rating scale of overt masculinity. 2

$I_{\text {W11llam D. Ward, "Process of Sex-Role Learning," Developmenta1 }}$ Psychology. I (1969), 163-168.

2Henry B. Blller, "Father Absence, Maternal Encouragement, and Sex Role Development in Kindergarten-Aged Boys," Chlld Developwent, XL (1969). 539. 
This writer saw two Iimitations to this study-the small sample size and the question of whether a paper and pencil questionnaire was a valid way to assess how much mothers actually encouraged masculine behavior.

Thus far, the ITSC as a techntque for measuring sex role proference has been discussed as well as criticisms and limitations of its usefulness. Several other technlques have also been used to assess sex role interests.

Sisson studied forty-five children enrolled in Head Start using a self-developed Instrument, "The Play Preference Kit," to measure sex role preference behavior and social competence. A tangible minlature preschool featured four "boys' areas" and four "girls" areas," and children were measured as to a degree of sex role orlentation (Who plays here?), sex role preference (Where do you want to play?), and sex role adoption (observed in a free play situation with the Play Preference KIt). The percentage of time spent in same- and opposite-sex play areas was calculated, and this percentage was used to delineate the four groups of children. The total social competence scores of the children in the group with $33-49$ percent of opposite sex play behavior were statistically signiflcantly higher than the other three groups. These children were characterlzed as flexible with a good sense of their own gender identity, which did not interfere with their utilization of activities and behaviors stereotyped as typical of the opposite sex when 1t was appropriate. Chilaren who showed no interest in opposite sex activities were less flexible 
and tended to exhibit only sex-typed social competencies. 1

Recall, knowledge, and preference for masculine and feminine

items were tested in 240 Anerican five and eight-year-old boys and girls by Nadelman, who had earlier studied English five-year-olds. Using a recall test, children recalled, knew, and preferred same-sex 1 tems more than oppositemsex 1tems. Girls' scores were less migldy stereotyped than boys'. Older children showed greater stereotyping in preference tests than younger children (confirming ITSC findings). Sex differences scores were greater in the working than in the middle class. In kindergarten, the middle-class children scored higher in knowledge of masculine than feminine items, and this finding was reversed in the working-class children. In comparison, American five-year-olds were less stereotyped than their English counterparts. 2

Studies which investigated sex role preferences or attitudes in relation to children's vocational aspirations and perceptions of occupations will be discussed later in this chapter.

\section{Parents' Influence on Sex Role Identity}

The way parents treat children may be the most important factor of all in the creation of sex role stereotypes. "When comparing the treatment of girls to boys, a critical difference emerges, girls are treated more protectively and are subjected to more restrictions and

$I_{\text {Lee Hansen Sisson, "Sex Role Interests and Social Competence }}$ in Young Children," Dissertation Abstracts International, XXXIV (1974), 4006 A (University of California-Los Angeles).

${ }^{2}$ Lorraine Nadelman, Sex Identity in American Children, Menory, Knowledge, and Preference Tests. U.S. Educational Resources Information Center, ERIC Doeument ED 084 029. June, 1973. 
controls; boys recelve greater achlevement demands and higher expectations," according to Frazier and Sadker. ${ }^{1}$

Parents subtly and persistently shape the behaviox and feelings of their offspring. The parents' attitudes about the sex of their child are evident before the baby is born, even before conception. It is most often hoped that the first child w1Il be a boy. When fetuses are active. kicking, and moving, mothers are more likely to interpret this as a sign the baby will be a boy. Reporting of the sex is the most dominant information given at birth. All birth announcements provide the sex of the child. and a new parent exclaims, "I have a girl (boy)," not "It's a healthy baby. "2

Children learn about sex roles early in their lives through relatively simple patterns that most people take for granted. Howe writes :

We throw boy-bables up in the air and coo over girl-bables and handle them delicately. We choose sex-related colors and toys for our chlldren from their earllest days. We encourage the energy and physical activity of our sons, just as we expect girls to be quieter and nore docile. We love both our sons and daughters with equal fervor, we protest, and yet we are disappointed when there is no male child to carry on the family name. 3

A 1971 study by Ban and Lewis concluded that types of parent attachment behavior directed toward infants varles as a function of the infants' sex. They studied infants in their first twelve weeks after birth in their homes, observing parent and infant behavior. They

$1_{\text {Nancy Frazler and Myra Sadker, Sexism in Schools and Society }}$ (New York: Harper and Row, 1973), p. 84.

2Michael Lew1s, "Parents and Children, Sex Role Development," School Review, LXXX (February, 1972), 231.

Howe, p. 76. 
classified behavior as proximal (touching, holding, rocking, behavior involving physical contact) or distal (looking at, smling, vocalizing, behaviors that can be performed at distance). From the earliest age and continuing through the flrst two years of life, mothers looked at and talked to their girl infants more than their boy infants. The proximal mode was more complex. For the first few months boys recelved more touching, holding, etc., than glrls. However, by age six months this trend had reversed. By six months and for the next year or two, girls received more proximal and distal behavior than boys. ${ }^{1}$

A second study by Lewis had further implications. He observed the free play activities in year-old children and in their mothers. Findings revealed that mothers encouraged boys to move away from the proximal mode at an earlier age than girls. He suggested that there may be a relationship between these early experiences and later adult behavior. He viewed proximal behavior and feeling as a positive valence (without documenting this premise, however) but pointed out that the competitive society does not view them as such and has prevented men from having these qualities. He cited the need for more research on differences between treatment of boys and girls. ${ }^{2}$

A child's sex role learning occurs through direct instruction: observation, insight, and problem-solving; and imitation through identification. From a very early age, initation is important in the rewards a child recelves. MeCandless and Evans writes

Other things being equal, imitation or modeling is greatest for models 1) who are like you; 2) who possess characteristics

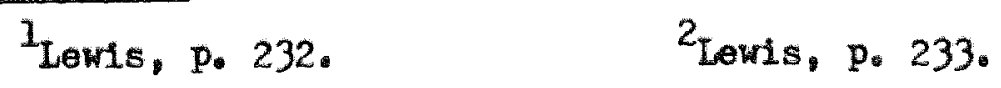


you desire; 3) who have rewarded you in the past; 4) who are accessible and thus provide opportunity for personal assoctation; and 5) who are powerful.1

For most children, parents possess much power. They are physically big, control many resources that chlldren want, usually demonstrate expertise in various important aspects of 1 ife, and are sources of needed affection and recognition. Because of these factors, parents are generally powerful nodels for their children. In addition, older siblings, peers, and other adults all have characteristics which children and youth model as they develop and mature. 2

Parental expectations and attitudes are internalized by theil children. Sex role stereotypes are included in these expectations. Mitchell reported a study by Mannes showing that mothers in the United States believed their sons should develop independence, a sense of responsibility, and some vocational role. When working-class and middle-class mothers of preschool children were asked to teach their chlld a new task, mothers of both classes were more achlevement-oriented toward their sons than toward their daughters and adopted a much more businesslike posture toward their sons. Parents in general tend to have higher achlevement expectations for their sons. ${ }^{3}$ Mitchell went on to say!

Feminintty and being female are soclally devalued by both sexes. Sexual stereotypes are perpetuated by women, nothers and teachers, as well as by men. Women have been

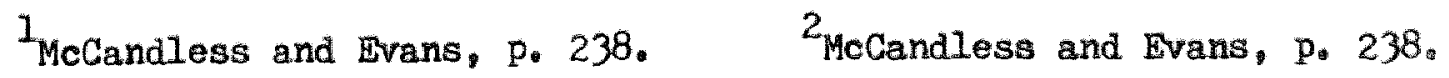

3Edna Mitchell, "The Learning of Sex Roles Through Toys and Books A Woman"s V1ew," Young Children, XXVIII (1973), 227. 
found to be even more condemning than men of women who break out of traditional roles. 1

Results of an experiment at a college in Maryland reported by Howe showed that boys and girls agreed that "1) boys were not smarter than girls nor girls smarter than boys but 2) daddies were indeed smarter than mommies:" 2 Mitchell believes that girls are torn by thelr ambivalence about their Identification with the female sex role. Girls identify wth their mothers but also absorb their nothers' ambivalence about woman= hood. ${ }^{3}$ Mitchell goes on to dramatize the fact that models in literature present assertiveness and independence as desirable characteristics only for boys. The most frequent model for girls in books is that of passive acceptance of supposedly feminine characteristics of gentleness, resignation, and domestic accomplishment. 4

Farents need to be arare of the messages conveyed in the books for preschoolers. In many books, little girls are often depicted as being on the ground as boys climb trees, as bringing tools to boys who do the work, and as cleaning up messes and keoping things tidy. In elementary school readers and textbooks, a sister is usually younger than a brother, and girls are fetching or carrying things while boys are making things. 5

In view of their tremendous impact on the sex role expectations of children, parents need to sharpen their awareness of the various

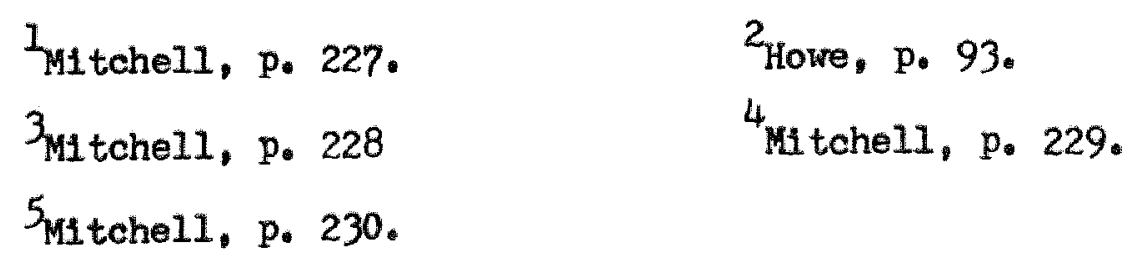

Howe, p. 93.

4 Mi tchell, p. 229 . 
subtle mechanisms restrlcting the healthy development of boys and girls in a world of equality. The earliest treatment of the child, the first toys, the deliberate or careless selection of picture and story books have an inmeasurable impact on the psychological growth of boys and girls. A further ramification is that parents are increasingly uncertain what sex-related values they should be conveying to theix children. Parents, too, need help in examining and claxtfying their own sex role expectations and stereotypes. Weltzman concludes !

In the past, social theorlsts have assumed that strongly differentiated sex-roles would facilitate a child's identification with the parent of the same sex. For example. Talcott Farsons has commented that "if the boy is to identify with his father there must be discrimination in role terms between the parents." More recently, however, Fhillip Slater has argued that adult role models who exhibit stereotyped sex-role differentiation may impede, rather than facilitate, the child's sex-role identification. Children find it easier to identify with less differentlated and less stereotyped parental role models. It is easier for then to internalize parental values when nurturance (the typically feminine role) and discipline (the typically masculine role) come from the saine person. 1

Impact of Teachers and Schools on Sex Role Stereotyping

Even though children internalize stereotypes about sox roles Iong before they enter school, educators have great opportunity to affect the sex role concepts of chlldren. Bernstein belleves that schools must assume leadership in changing the sex role stereotypes

$1_{\text {Lenore Weltzman, "Sex-Hole Sociallzation in Plcture Books for }}$ Pre-School Children," American Journal of Soclology, LXXVII (May, 1972). $1146-1147$. 
handed down by society. ${ }^{1}$ Zach and Price write,

It is difficult to imagine that we can meet the educational needs of all children--a goal repeatedly stated-if these needs are, in part, determined in advance by the sex of the pupil, and by artifactual expectations of his teachex. 2

Three areas of sex role stereotyping in the public schools were investigated by Saarlo, Jacklin, and Tittle. Their research documents the extent and kind of sex role stereotyping in the kindergarten to third grade textbooks of four major publishers. The section on educetional testing raises the issue of sex bias in item content and language usage and shows the presence of sex role stereotyping in test batteries from major test publishing companies. The curriculum section discusses the presence and ramifications of different curriculum patterns for males and females. 3

Sadker and Sadker believe that school experlences channel chil= dren Into sexual stereotypes in a variety of subtle ways. Teachers transfer their expectations in many nonverbal ways to their students. 4 Many educational researchers are also examining the language of the classroom to determine the nature of verbal interaction. ${ }^{5} 0$ Donnell

${ }^{1}$ Jean Bernstein, "The Elementary School, Training Ground for Sex Role Stereotypes," Personnel and Guidance Journal, LI (1972), 97.

2Lillian Zach and Michelle Price, The Teacher's Part in Sex Role Relnforcement, U.S., Educational Resources Information Center, ERIC Document ED 070513,1973, p. 10.

3 Terry N. Saario, Carol Naby Jacklin, and Carol Kehr THttle. "Sex Hole Stereotyping in the Public Schools," Harvard Educational Revlew, XIIII (August, 1973), 386-416.

4 Myra Sadker and David Sadker, "Sexism in Schools" An Issue for the 70"s," Education DLgest, XXXIX (Apr11, 1974), 58.

${ }^{5}$ Sadker and Sadker, p. 59. 
writes about sexism in language itself, both written and spoken: Whether language shapes our culture or culture shapes our language, women have been categorized and stereotyped, and our language helps perpetuate this division between the sexes." 1

Most of the research on stereotyping of sex roles and expectations of teachers has been done with elementary and secondary teachers. With increasing numbers of children enrolled in preschools and day-care centers. the influence of preschool teachers deserves attention. McCandless and Evans report research conducted on sex role behavior in two nursery schools. They found that sex differences in play behavior exist among three-year-old children. Boys preferred block-bullding and transporta= tion toys while more girls preferred painting and artwork. Overwhelmingly, children engaged in the preferred activities for their sex. GIrls, for example, spent less than 8 percent of their time in "boyish" activities, boys 13.5 percent of their time in "girlish" activities. When a tally was made of how often four women teachers rewarded children for sex-preferred activities, teachers were found to be rewarding both boys and girls for doing things to be feminine in nature. Femininepreferred behaviors constituted 83 percent of the sex-preferred behaviors that received positive teacher reinforcement (coment favorabiy, initiate, or join behavior). ${ }^{2}$ MoCandless and Evans discussed further Implications:

Holly Snith O'Donnel1, "Sexism in Language," Elomentary Eyy11sh. L (October, 1973), 1067.

TeCandless and Evans, p. 236. 
In this study, wo see the active role played by the peer group in maintaining "approprlate sex-role behavior," to the degree that, for the boys, the peex group overrode the influence of the teachers... .

Girls apparently learn feninine stereotypic "sex appropriate" behavior principally through rewards, probably from fathers more than mothers, and certainly from girl peers, teachers, and at least by adolescence, from male peers. The evidence is plentiful that girls do not identify with their gender role as early and perhaps not as firmly as boys. As might be expected (and some evidence supports the expectation), they do identify with their sex-role more congruentiy than boys, perhaps because their learning occurs more through reward and less through punishment.1

A survey of twenty-four prekindergarten teachers was reported by Chasen, who found that teachers seem to resist the implications of stereotyping and that stereotyping did exist in teachers' expectations as well as attitudes. One of the most striking findings was that teachers felt that in the classroom there was equality between girls and boys. But this equality seems to be largely a myth because sex role stereotyping appeared in almost all areas in the classroom. 2

Lee and Kedar analyzed the interaction between sex role and "pup11 role" in the early chtldhood setting. They postulated that teachers and schools have a demonstrated investment in socializing children to a passive, docile, and dependent role, beginning at the preschool level. They cited studies which indicate this "pupil role" corresponds closely to the traditional female sex role and is incongruent with the standard male sex role. Thus, boys may experience

TMeCandless and Evans, pp. 236-237.

2 Barbara Chasen, "Sex-Role Stereotyping and Prekindergarten Teachers," Elementary School Journal, IXXXIV (January, 1974), 233. 
conflict and stress in school while girls accommodate to the passive style associated with pupll role. ${ }^{1}$

Studies of teacher behavior and expectations demonstrate that sex role stereotyping is a common occurrence in elementary classrooms, actively reinforcing the sex role stereotypes learned in the home environment. Mulawka, in his study of twenty-eight kindergarten through grade three classrooms, had statistically significant findings-owhen positively reinforcing children's behavior, teachers did not differentiate between the sexes; when negatively reinforcing chlldren's behavior, teachers used more negative reinforcement patterns with boys than with girls; the teachers did not respond elther positively or negatively to crylng behavior; teachers didn't differentiate between sexes when assigning work or play activities, and teachers did delegate far nore masculine-stereotyped chores to boys than feilnine-stereotyped roles to girls when assigning housekeeplng tasks. 2

Letvitin and Chananie asked forty female teachers to respond to descriptions of hypothetical male or female students. Their results support the view that teachers promulgate traditional sex-typed behaviors -expecting, encouraging, and rewarding assertiveness in little boys and dependency in little girls. Teachers also liked achieving girls better

${ }^{1}$ Patrlck C. Lee and Gita Kedar, Sex Role and Pupil Role in Early Childhood, U.S., Educational Resources Information Center, ERIC Document ED $100491,1974$.

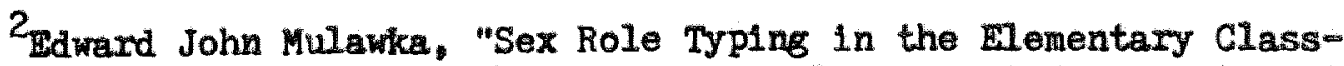
room as Reinforcement of Sex Role Stereotypes Learned at Home," Dissertation Abstracts International, XXXIII (1973), 6472 A (Wayne State University). 
than achleving boys. 1

Kagan's study with 240 second and third-grade-children used a disguised concept transfer to get male-female responses. He taught chlldren nonsense labels to represent a construct. He found that elementary school children, both boys and girls, labeled school objects such as blackboard, book, page of arfthmetic, and school desk as feminine rather than neuter or masculine. The findings suggest that superior academic performance of girls in the primary grades may be facilitated by the girls' view of school as congruent with their sex role, whereas boys were nore ambivalent. ${ }^{2}$

As boys and girls progress through school, their opinions of boys become higher and correspondingly, their opinions of girls become lower. Grade school boys are convinced it was great to have been born a male while elementary school girls are less enthuslastic about being female. 3 The separation of boys and girls for seating, hanging up coats, the cholce of class helpers, and for certain classes calls attention to sex distinctions and sex roles.

The effects of differential treatment by teachers has been discussed in terms of both boys and girls. School is so much a woman's world that it can be hard on some elementary school boys and may seem

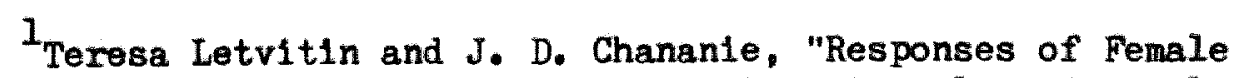
Primary School Teachers to Sex-Typed Behaviors in Male and Female Ch1ldren," Child Development, XLIII (December, 1972), 1315.

2 Jerome Kagan, "The Child's Sex Role Classification of School Objects," Child Developsent, XXXV (1964), 1051-1056.

Myra Sadker, "Are You Guilty of Teaching Sex B1as?" Instructor. LXXXII (August, 1972), 80. 
to have little relevance to them. Bernstein points out that boys aro 1int ted by the lack of adult male role models at school-othey don"t see men playing the role of loving, nurturing teacher of young children. 1 Stone and Church write:

The accomplishment-oriented role expectations for boys, plus the conflicts in expectations, plus the lack of adequate models, may account for the fact that boys are consistently more prone than girls to minor and major emotional, scholastic, and behavloral problems (although mortality statistics suggest that boys may be biolog1cally more vulnerable than girls).2

Studies have demonstrated that boys make up the majority of teachers' behavioral problems and that teachers tend to discipline boys more harshly than girls. A boy may learn that he can get attention and respect from his teachers and peers for nonconforming behavior. Thus, teacher criticlsm, a seemingly negative response, may actually lead boys toward greater independence, autonony, and activity. ${ }^{3}$ For example, boys, more fldgety in the early grades, tend to have more trouble in controlling this behavior, don't get the rewards girls do for this control, yet later may be freer in their approach to learning.

Schools give girls contradictory messages. Girls are encouraged to be good students, to learn, to perform, to achieve. Yet these same girls are criticized if they are too competitive or take too much pride

$1_{\text {Bernstein, p. } 98 .}$

2 Joseph L. Stone and Joseph Church, Childhood and Adolescence: A Psychology of the Growlng Person (New York i Randon House, 1968), p. 390.

3 Betty Levy, "Do Teachers Sell Girls Short?" Today's Education, LXI (Decenber, 1972), 27-29. 
in their academic accomplishments. ${ }^{1}$ Another example of differential treatment is that teachers tend to grade girls higher even though boys may do as well on achievement tests. ${ }^{2}$ However, many people have been unaware of the subtle negative effects schools have had on girls. They fall to realize that girls are being doubly trained--at home and at school-- to be docile, dependent, and conforming. ${ }^{3}$

Many materials and books for children also reinforce traditional sex role sterootypes. Mulawka found teachers' displays of pictorial and written materials showed significantly more references to males than females in both wage occupations and leadership roles. These findings were also found in the pictorial contents of textbooks he examined. ${ }^{4}$ Books winning Caldecott Awards and three other groups of children's books were the focus of a study by Weitzman. Her findings suggest that the girls and women depicted in these books are a dull and stereotyped lot. Iittle girls recelved attention and praise for their attractiveness, while boys were admired for their achlevements and cleverness. Most women in the picture books had status by virtue of their relationships to specific men--they are the wives of the kings, judges, adventurers, and explorers, but they themselves are not found in these roles.

There were no working women in the Caldecott sample. Through

\footnotetext{
$1_{\text {Bernstein, p. } 98 .}$

2 Margaret Conant, "Learning to Be Boy, a Girl, or a Person,"
} PTA Mazazine, LXVI (1972), 20.

3evy, pp. 27-29. 4 Mulawka, p. 6472. 
books, Girls have been taught to have low aspirations because there are so few opportunities portrayed as avallable to them. The books do not tell girls that as wonen, they might find fulfillment outside of their homes or through intellectual pursuits. Women are presented as excluded from the world of politics, sports, and science. Their future world is presented as consisting of glamour and service. It is clear that the storybook characters reinforce the traditional sex role assumptions. These books are read over and over at a time when children are in the process of developing their own sexual identities and are most impressionable. Weltzan concludes:

Picture books play an important role in early sex-role socialization because they are a vehicle for the presentation of societal values to the young child. Through books, children learn about what is right and wrong, and they learn what is expected of chllaren their age. In addition, books provide children with role modelsinages of what they can and should be like when they grow up. 1

Textbooks in school continue the trend of sex-typing when children reach school age. A task force of the National Organization for Women in Princeton, New Jersey, Inltiated a twomyear study of sex role stereotyping in children's readers. The purpose of the study was to find a reading series which portrayed males and females in a nonstereotyped manner. Despite the fact that task force members read 134 books from twelve different publishers and carefully documented 2.760 stories, no such series was found

Ieltzman, "Sex-Role Soclalization in Plcture Books for PreSchool Children," p. 1126. 
The ratio of boy-centered stories to girl-centered stories was 5 to 2 ; the ratio of storles with an adult male character to an adult female character was 3 to 1; the ratio of male biographies to female blographies was 6 to 1 . Boys in the storles butlt and created things and used their wits. Girls rarely appeared in these roles. Boys showed inftlative and were strong and brave girls were rarely depicted as having these characterlstics. When a girl mastered a grown-up skill, it was usually a domestic one. Boys were competitive, girls were not. Girls did not act independently; they were smaller and more fearful than boys.

The books showed adult females as jobholders or mothers. Mothers in the storles were colorless, ind less creatures, never shown as having any interests of their own. Fathers on the other hand, were plctured as well-rounded, vibrant adults. It is father who does things with the chlldren, helps them build things, takes them on outings, and solves their problems. Father is the person with whom children have fun. 1

Jacobs and Eaton discussed the Implications for teachers:

Clearly, this is not a fair or balanced picture. As products of a sexist culture, teachers carry with them blases about what boys should be and what girls should be which may be no longer useful. The world into which our children will emerge is different from the conventional stereotype (mother, father, two children, dog and cat, white frame house). We must begin to face this and prepare children for life as it really $1 \mathrm{~s}^{2}$

Primary arithmetic books continue the same trend. Boys are depicted as making things and earning money while girls are shown as cooking or spending money on such things as sewing equipment. 3 in the United States, content analysis studies reveal similar stereotyping In textbooks from elementary schools through high school. Book reviews and protests by parents and teachers are beginning to call the attention

$1_{\text {Carol Jacobs and Cynthia Eaton, "Sexism in the Elementary }}$ School," Today's Education, LXI (December, 1972), 20.

$2_{\text {Jacobs and Eaton, p. } 20 .}$ ${ }^{3}$ Conant, p. 19. 
of authors and publishers to the slanted material they provide.

School staffing itself is an example of sex role stereotyping.

In 1928, 55 percent of the elementary principals were women. In 1971, although women comprised 88 percent of the elementary school teachers, only 22 percent of the principals were women. The fact that only two of the nation's thirteen thousand district superintendents were women ${ }^{1}$ is an important evidence of sex-typing.

McClure and McClure effectively summarized the necessity for educators to become more aware of the effects of sex role stereotyping:

Sex stereotyping occurs in the school courses, in the text materials, in the extra-curricular opportunities, in the process of "misguldance," and the very management of school . . . In an age of accountability we should be deeply concerned over the kind of product, or student, who emerges from our schools. If we allow stereotyping to persist we w111 have crippled personallties to treat in later years. 2

\section{Teleyision's Influence on Sex-Typing}

Television, another important educational influence on children, has perpetuated sex role stereotypes. A group of feminist psychologists and educators brought this fact to the attention of a producer of "Sesame Street." Among the unintended learnings being transmitted to preschool children were those about male activity and female passivity. As a consequence, "boys tend to disparage girls and at even greater psychologlcal

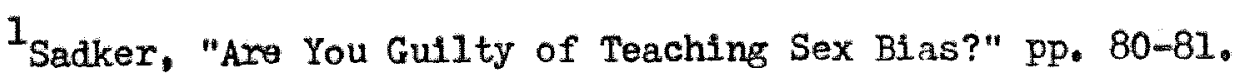

2John W. McClure and Gall T. McClure, "Cinderella Grows Ups Sex Stereotyping in the Schools," Educational Leadership, XXX (October, 1972). 33. 
cost, girls leam to disparage themselves," according to Somerville. ${ }^{1}$

Concrete recommendations were made for eliminating sex role stereotyping in future planned episodes both quantitatively and qualitatively, avolding showing consideration and concern as being sex linked with girls; introducing counter-stereotypic characters such as a woman architect and research scientist, and portraying the working mother to reflect the realities in children's 11ves. 2

Dohrmann studied representative samples of a week of children's television programing, including variety-educational, cartoons, and drame program types. She found that the male sex is the most visible gender symbol in chtldren's television with its 78 percent share of all characters compared to its real life 45 percent share of the population. Moreover, males were most apt to dominate those characterlations of ascribed power or authority, extent of role (lead, major roles), and occupations. Males were more likely to exhibit active, masterful behavior. 3 The implications of her findings about television programing add to the growing realization of the ramiflcations involved in sex role stereotyping.

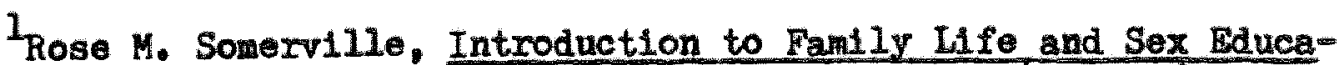
tion (Bnglewood Cllff, New Jersey: Prentice-Hal1, 1972), p. 76.

2 Somerville, p. 76 .

Rita Meade Dohrmann, "Children's Television Programing A Sex-Socialization Agent," (unpublished Master's thes1s, Drake University. 1974), p. 177 . 
VOCATIONAL DEVELOPMENT OF YOUNG CHILDREN AND EFFECTS

OF SEX-TYPING ON THEIR ASPIRATIONS AND ATTITUDES TOWARD OCCUPATIONS

Vocational Development of Children

The formation of vocational attitudes and values begins very early in life and seems closely related to vocational choice, according to Fulton, who also pointed out the lack of developmental research in childhood years. $^{1}$ She undertook a study to investigate what children know about work at different points in time to see where children were on a developmental continuum. She developed a Career Concepts Inventory for use with 225 children from preschool to grade flve to measure how children perceived selected characteristics of the work world. One facet of her study used pictures to investigate knowledge children had about fifteen occupations. Among her conclusions was that:

The older the children the more frequently they answered that both sexes could do most jobs. The preschoolers and first graders percelve more occupations as being exclusively elther male or female. ${ }^{2}$

Several criticisms can be made of Fulton's study. She did not report the differences between boys' and girls' responses nor the high degree of stereotyping along traditional sex role lines. The drawings of occupations also included workers pictured that perpetuated traditional stereotypes. One section called "picture absurdities" counted a response as correct if a child chose as unusual or strange a woman

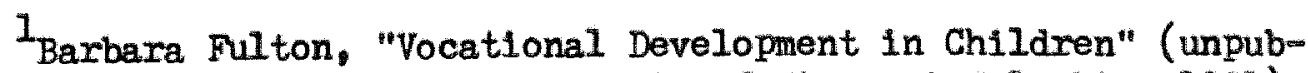
lished Doctoral dissertation, University of Missouri-Columbia, 1971). p. 30 .

2fulton, p. 79. 
operating a television camera and a man taking dictation. ${ }^{1}$ Her summary statement mentioned the tendency with increasing age for children to have a fairly accurate perception of the sex of the workers in different occupations. ${ }^{2}$ While chilaren may indeed recognize the occupations usually held by one sex or another, this writer would point to the need for opening choices of occupations to both sexes.

A study by Parker in 1961 investigated the nature of children's concepts of fourteen occupations. He found mean conceptual scores obtained by fourth and sixth-grade children were significantly higher than second-grade means in each of seven occupational areas. He concluded that children appeared to have attained a high level of conceptual understanding of occupations. 3

Vocational values have been the subject of several research studies. Reporting the results of an investigation between self-concept, sex, and the relationship between these with work values of ninety-nine fifth and sixth-grade children, Hales and Yackee confirm that work vaiues are held by elementary children and that boys and girls differ in some of their work values,

Boys placed greater value than did girls on work which involves manipulation of tools, materials, and utensils, gives the individual supervisory responsibilities, and offers the chance to be known for their work. Boys also placed greater value on jobs which provide an opportunity

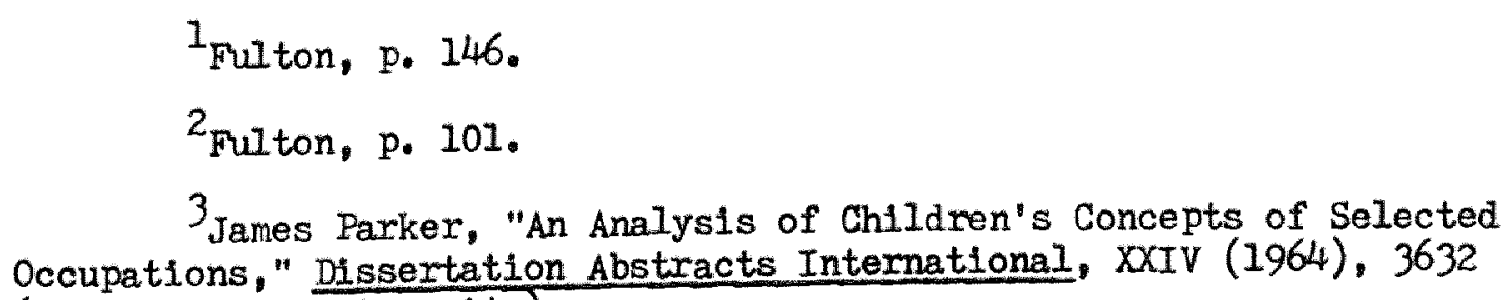


to work with 1deas and data. ${ }^{1}$

This writer would ask why Hales and Yackee did not report what girls valued.

Cooker used a vocational values inventory with 240 children in grades four, five, and $s i x$ and found that "boys value such things as money and control more than do girls, whlle glrls are seen to place more importance on altruism and helping others." 2 They found little change in vocational values over the middle elementary school years and made the implication that in order to assure a maximal development of the valuing process, schools cannot wait unt1l the higher grades to aid children in examination of values. 3

Chaney's findings also suggest an early crystallization of values for many children. He reports sex differences in the expression of values being evident by the fifth grade level,

Consequently, counselors and teachers should be involved in determining the nature of sex differences in vocational values and aiding children in the understanding of sex roles in the culture and in the world of work. 4

Another conclusion reached was that children from the lower economic communities valued money, job control, and prestige aspects of work more

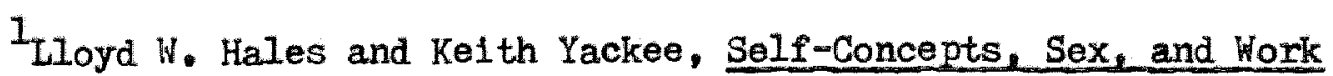
Values, U.S., Educational Resources Information Center, ERIC Document ED 090 459, Apri1, 1974, p. 4.

${ }^{2}$ Phillip G. Cooker, "Vocational Values of Children in Grades Four, FIve, and Six," Elementary School Guidance and Counseling, VIII (December, 1973), 116.

${ }^{3}$ Cooker, p. 117 .

4 Reece Chaney, "Vocational Values of Chlldren as They Relate to Economic Community, Grade Level, Sex, and Parental Occupational Leve1," Dissertation Abstracts International, XXIX (1969), 2957 A (Ohio University). 
than their counterparts from higher economic communities. The latter group placed greater value on the self-realization aspects of work. 1 In comparing child rearing practices of middle and lower-class families and the relationship with self-concept and vocational behavior of sixth-grade children, Atlas found that middle-class student respondents and lower-class student respondents were not signiflcantly different in the relationship they showed between their level of vocational preference and their level of vocational expectation. However, a significantly higher Ievel of vocational preference and vocational expectation was demonstrated by the middle-class children than their lower-class counterparts. 2

Brook et. al. studied parental aspirations for their children as well as first and fifth-grade children's aspirations. High socio-economicstatus children were found to have significantly higher aspirations than the low socio-economic-status children. They also found that children's aspiration levels increased with age:

Whereas among younger children, girls had higher occupational asplrations, there was a reversal among the older children so that fifth-grade boys' aspiration levels were higher than flfth-grade girls' aspiration levels. 3

Social class differences in aspirations were stronger among the younger

$$
1_{\text {Chaney, p. } 2956 .}
$$

2 John Wesley Atlas, "The Influence of Child-Rearing Practices on the Self-Concept and Vocational Behavior of Middle and Lower-Class Children," Dissertation Abstracts Intermational, XXXIV (1973), $563 \mathrm{~A}$ (Wayne State University).

3 Judith S. Brook and others, "Aspiration Levels of and For Children, AGe, Sex, Race, and Socloeconomic Correlates, "Journal of Genet1c Psychology, CXXIV (March, 1974), 9. 
children, whereas sex differences were sharper among older children. Both social class and race were not found to be correlated with parental occupational expectations for their children. Parents' occupational, as well as educational, aspirations were higher for boys than for girls, especially for boys and girls in fifth grade. ${ }^{1}$

The developmental sequences involved in the rocational interests and knowledge of children have been incorporated into Iowa's career developmental model. It was built on the premise that children pass through a series of stages--awareness (k1ndergarten through grade 3), accommodation (grades 4-6), exploration (grades 7-9), preparation and exploration (grades 10-12), and occupational entry. Activities were designed to develop positive student attitudes, values, knowledges, and skills toward self and the world of work. The school's involvement in career education was regarded as beginning in kindergarten and continuing throughout formal education with alternatives for recycling to obtain further training in adult years. ${ }^{2}$

\section{Importance of Occupational Information}

Knowledge about occupations and the world of work, understood in relation to self-knowledge, is important if a child is to exercise his/ her inherent right to freedon of choice in occupations. Goodson provided background for an elementary level program of occupational information by

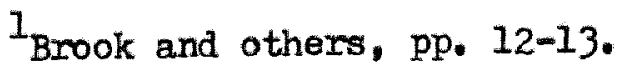

${ }^{2}$ State of Iowa, Department of Public Instruction, Models for Career Education in Iowa (Des Molnes, Iowa: Department of Public Instruction, 1973-1975). 
conducting individual interviews with 180 children in grades three through eight to learn their concepts of the world of work. The children revealed their interests, knowledge, and attitudes related to vartous occupations and reasons for working. Some children were quite unaware of work while others were well informed and had specific vocaw tional goals. Her data were used in developing telecasts and other means of presenting occupational information. Interesting findings reported were that younger children appeared to conceptualize occupational functions as activities rather than as work per se (as with community workers), that the younger children tended to remember occupations within their orm experience boundaries, and that the greatest proportion of occupations reported were in the service category. The majority of children named an occupation but a few simply said they would get a good job. Children expressed a diversity of interests as well as disinterests-occupations they would definitely not wish to do. ${ }^{1}$

Exposure to an occupational unit increased children's scores on an inventory of vocational knowledge and attitudes in a study reported by Harkness. However, girls' increased knowledge did not influence them to change their choices of future occupations from their initial feminine selections. Boys also continued to select the traditional masculine glamour occupations. ${ }^{2}$ Contrasting findings were reported by Bucher,

$1_{\text {Sylvia Goodson, "Chlldren Talk About Work," Personnel and }}$ Guidance Journal, XIIX (October, 1970), 131-136.

2 Carol Harkness, "The Relative Impact of Identified Vocational Development Variables on the Occupational Knowledge and Attitudes of Elementary School Children," Dissertation Abstracts Intemational. XXXIV (1973), 566 A-567 A (University of Virginia). 
who demonstrated that presentation of an occupational unit significantly increased students' knowledge of occupations and their preferences for traditional opposite sex occupations as vocational preferences. This held true for both sexes in her study. In addition, as a student"s knowledge increased, his or her attitudes toward occupational roles of men and women became less sex role stereotyped. ${ }^{1}$

Occupational Interests and Asplrations

Sex role preference in relation to children's vocational aspirations has been the toplc of several recent studies. Determining the early aspirations of boys and glrls was the purpose of a study by Looft in 1971. Thirty-three boys and thirty-three girls, who were first and second-grade pupils in two Catholic parochial schools, were informally asked, "What would you like to be when you grow up?" and secondly, "What do you think you really wlll do when you grow up, when you are an adult?" Boys named elghteen different occupations, with football player and policeman most frequently named. On the second question, twenty-three boys changed from their initial response to other vocations perceived as desirable. The girls named only a total of elght occupations--twentyfIve named either nurse or teacher. Only fourteen girls changed from their original cholce on the second question. Looft concluded that girls, especially, learn early that certain adult statuses were open to them and that these were few in number, reflecting a recognition of

$I_{\text {Carol Hope Bucher, "The Impact of a Non-Stereotyped Sex-Role }}$ Occupational Unit on Elementary School Children's Occupational Knowledge. Vocational Aspirations, and Expressed Occupational Attitudes," Dissertation Abstracts International, XXXV (1974), 2672 A (University of VIrginia). 
traditional sex role expectations, none expressed the desire to be a politician, lawyer, or scientist. A few girls said they would be mothers, but no boy sald he would be a father. ${ }^{1}$ Hewitt's study with Dutch children confirmed Looft's findings that with increasing age, boys perceived job perspectives as broadening while girls responded with just a few alternatives, primarly teaching and nursing. 2

Swick and Carlton examined occupational interests of kinder garten children and found a wide diversity of interests, indicative of the awareness stage of development. However, they conclude that the choices did not include the breadth of awareness needed in a rapldiy changing world of work. No relationship was found to exist between the parents' occupations and the occupational cholce of their children. Children chose more leadership-oriented tasks than their parents and were more oriented towand service at this point in their development. 3

Elght and ten-yearold children differed in their occupational preferences in a study conducted by Brady. He reported differences by socio-economic class, sex, and age. Girls at both ages and from all socio-economic levels in the sample limited themselves much more in theix

\section{Iooft, p. 366 .}

${ }^{2}$ Lymn Stewart Hewitt, "Age and Sex Differences in the Vocational Aspirations of Elementary School Children," Journal of Social Psychology, XCVI (1975), 176.

Kevin J. Swick and Mary Ellen Carlton, "An Examination of Occupational Interests of Kindergarten Children: Implications for Curriculum Development," Reading Improvement, XI (Spring, 1974), $58-61$. 
range of occupational cholce than did the boys. More than half of the girls chose teacher, nurse, or housewlfe as an occupation. ${ }^{1}$ Hahn asked teachers from around the country to collect expressions of students" goals. She recelved hundreds of responses from kindergarten through grade twelve classes and found that,

an overwhelming majority of females said they wanted to be nurses and teachers. Secretary, stewardess and model ranked next in popularity. . Males showed an interest in a greater variety of jobs. 2

The work of Kirchner and Vondracek filled a much needed void in research about the aspirations of preschool children. As part of a forty-five minute assessment interview, they told 282 three to six-yearold children in Pennsylvania day-care centers, "A (boy, girl) can be all sorts of things when (s)he grows up. What would you like to be when you grow up?" 3 Results were analyzed in terms of number of aspirations mentioned and category of response. The categorles for coding the responses were as follows:

1) All adult, a category of the following three subcategories which define 1 ts scope:

a) Specific occupation

b) Adult, nonoccupational adult status, e.g. "be a man"

c) Parent

2) older child, attributes of older, bigger children, e.g. "be a Girl Scout," "be taller"

Tobert Faul Brady, "An Examination of Selected Varlables Affecting the Vocational Development of Elementary School Children," Dissertation Abstracts International, XXXII (1972), 3682 A (University of Cincinatt1).

${ }^{2}$ Carol Hahn, "The Me I Want To Bei Students' Aspirations in the Seventies," Social Education, XXXVIII (April, 1974), 341.

3 Kırchner and Vondracek, p. 2. 
3) Same child, response indicative of lack of projection into more mature roles, e.g. "be a boy just like I am"

4) Fantasy, fictitious characters or roles no longer present to any significant degree in contemporary society, e.g. Batman, princess, cowboy

5) Nonhuman, animal and inanimate objects, e.g. doggie, tiger, and a "bath tub, so I could drink lots of water"

6) Other, responses not classifled into the preceding categories and not sigpiflcantly frequent to warrant additional categories. 1

Major findings of the study can be sumarized as follows

Aspects of vocational development follow an orderly pattern in early childhood. During the preschool years the child comes to project himself into his adult future, to see himself one day as an adult.

Even in the preschool years, significant sex and race differences are evident in vocational behavior. The largest percentage of children gave responses categorized as All Adult and within this category, the mention of a speciflc occupation was most frequent. The All Adult category increased significantly with age and within the All Adult category, speclfic occupational aspirations increased markedly. There were decreases with age in Nonhuman, Older Child, and Same Child responses.

Boys and girls equally frequently gave responses clas sified as All Adult. But boys more often projected themselves in terms of an adult role in general and girls more often projected thenselves in terms of the specific role of parent.

Boys' cholces were more evenly distributed among occupations, while girls' cholces clustered around two occupations--nurse and teacher.

Findings that more frequent Older Child responses by girls and more frequent Fantasy responses by boys supported the notion that girls are more reality bound than boys.

Blacks tended to glve fewer responses than Whites in the All Adult category. Within this category, Blacks gave

\footnotetext{
Kirohner and Vondracek, p. 3.
} 
fewer Specific Occupation responses and more Adult responses. Blacks also gave more responses in the Same Child and Older Child categorles. These findings suggest that the Black children are less mature in their vocational development from the standpoint of mastery of the task of projection into the vocational future. 1

The research by Kirchner and Vondracek adds support to the bellef that the preschool period can be viewed as a bona fide stage in voca tional development. During these years the child cones to conceptualize $\mathrm{hlm} / \mathrm{herself}$ as one day belng an adult and having an occupation. The sex and race differences in the early years suggest that efforts toward achieving equality of vocational opportunity should not neglect the very young.

\section{Perceptions of Roles Open to Men and Women}

In 1971 and 1972, two studies dealing th sex sterootyping were conducted on school children in three suburbs of Seattle by Iglitzin. In the first study, in which she collaborated with Fledler, 290 fifth graders took part; in the second, 147 flfth graders (about ovenly divided by sex in both studies). 2

The first study involved a serles of questions designed to show sex stereotypling based on views of career and employment patterns, soclal roles in home and family, and the child's view of his/her future life as an adult. Both boys and gixls demonstrated sex stereotyping (as measured

\footnotetext{
1 Kirchner and Vondracek, pp. $4-6$.

2 Lynne B. Iglitzin, "A Child"s-Eye V1ew of Sex Roles," Today"s
} Educat1on, LXI (December, 1972), 23-25. 
by the response "men" or "women" rather than "elther" or "both" to the questions). However, significantly higher proportions of girls had nonstereotyped responses in all categories. Results indicate strong sex role stereotyping by the fifth-grade level,

Career and employment patterns, A majorlty of both sexes thought that bosses, taxi drivers, mayors, factory workers, and lawyers should be men and that nurses and house cleaners should be women. Stereotyping was common for both boys and girls. In fact, in some cases, girls were even less inclined than boys to see traditionally masculine jobs become feminine jobs. - However, girls were more willing to see jobs open to elther sex.

Home and family, Fifth graders have been thoroughly inculcated with a sex-typed view of home and household: Women wash dishes, cook, dust, scrub floors and get up at night with a sick child. Men pay bills, fix things, and weed the yard. The men's list was shorter than the women's... though the girls showed a slightly greater tendency to see both parents performing household tasks.

Personality traits: At least 60 percent of the girls saw themselves as kinder, better behaved, more serlous, and better in math than boys. . . The majorty of girls saw boys as fighting more and as better in science. The aggressiveness-gentleness continuum offered a striking example of agreement by both sexes close to 90 percent of boys and girls saw boys as fighting more and about 75 percent of boys and 85 percent of girls saw girls as kinder.

Sextyping in girls' view of the future, The patterns of traditional sex typing carried over into their career asplrations and descriptions of their lives as adults. . . Girls had varled job and career aspirations, albeit heavily weighted toward traditional female occupations. Only 6 percent sald they would simply be a mother or housewife. However, the girls' projected description of a typical day as an adult showed a marked discrepancy between their stated career goals and their descriptions of an actual day. Girls in the sample emphasized marrlage and family much more than boys in the sample. . . Boys tended much more to focus exclusively on details of job and career.

$$
{ }^{1} \text { Iglitzin, pp. 23-24. }
$$


One varlable that seemed to be relevant in determining which chlldren had less traditional stereotyped views was whether or not their mothers worked outside the home. Iglitzin's data support other findings that children with working nothers--especially girls--had more IIberal views on roles of men and women in society. ${ }^{1}$ Iglitzin's second study conflrmed the sex stereotyping attitudes but did not show a correlation between stereotyping and feminization in the girls as an explanation for their low politicalization scores. ${ }^{2}$

Burgette used a questionnaire to investigate the aspirations and perceptions of future life-styles of $190 \mathrm{fifth}$ and sixthorgrade girls. Her findings about girls' emphasis on marriage concur with Iglitzin's. Wh1le 65 percent 11sted a professional occupational chore, 95 percent expected to marry ( 85 percent of those by age 21). The discrepancies became apparent when looking at the training periods involved and the fact that 50 percent sald they would not work after marriage. Burgette suggested that the females' goals could be expanded by encouraging further consideration of occupations they view as exciting but not realistic. 3

Schlossberg and Goodman studied kindergartners and sixth graders in two elementary schools (the report did not specify the number of children in the sample) to discover the degree to which elementary school

$$
1_{\text {IglitzIn, p. 24. }} \text { Iglitzin, p. } 25 .
$$

3 Patricia Roop Burgette, Perceptions of Fifth and Sixth Grade Females of Vocational Goals and Bxpected LIfestyles, U.S., Educational Resources Information Center, ERIC Document ED 082 068, 1970, pp. 6I62. 
children hold stereotypes about occupations based on sex. Children were asked to respond to twelve drawings, representing work settings of $s i x$ occupations traditionally considered feminine and six traditionally considered masculine. In addition, each child was asked, "What do you want to be when you grow up?"

Data were analyzed in terms of number of stereotyped responses. Their data indicate that there was no appreciable difference in stereotyping between kindergartners and sixth graders; the sixth graders at the model citles school held more stereotypes than those at the middle Income school, the chtldren excluded women from men's jobs more than they excluded men from women's jobs; with few exceptions, the children chose jobs for themselves that fall within the usual stereotypes (1.e. most children felt elther men or women could be doctors or nurses but the boys all chose to be doctors and the girls, nurses); and there was some disparity between the amount of stereotyping of one occupation and another. The authors concluded that the children's early notions of differential achlevement for men and women need to be changed. 1

\section{EFTORTS TO COMBAT SEXISM}

Educators have an opportunity and responsibility to challenge and correct the detrimental effects of sex role stereotyping. Levy states: First they must realize that schools mirror the elitism, racism, and sexism in society. Efforts to change sexism

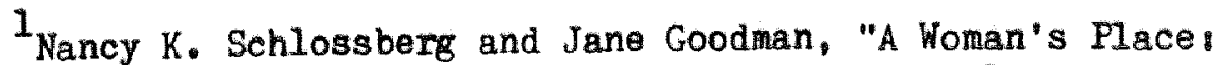
Children's Sex Stereotyping of Occupations," Vocational Guidance Quarterly, XX (1972), 266-270. 
In schools must be perceived as part of a large and long-range struggle to change the inequalities which schools maintain and perpetuate. 1

Sweden is one country committed to promoting sexual equality. Through its National Board of Education. Sweden has undertaken the task of reeducating the entire population away from traditional sex role prejudices. ${ }^{2}$

Weeks suggests that parents and teachers should help children develop more flexible role concepts. He recommends consclousnessmaising for preschool staffs and parents to discuss stereotypic role models, to examine books and cumriculum materials, to include non-traditional role models for young children, and to integrate play areas. ${ }^{3}$ Joffe also emphasizes the importance of soclalization in nursery schools and the necessity of examining the specific role played by such institutions in sex role socialization. 4

The schooling of tomorrow's women was discussed by Mitnuchin, who recommends the following goals or tasks for a school:

Minimization of stereotypes; provision of broad exposure to experiences, ideas, and models; education in skills for choice, problem solving, and evaluation; and enhancement of self-differentiation and self-knowledge. 5

$1_{\text {Levy, p. } 29 .}$

2Roger Choates, "Eroding Sex-Role Stereotypes," Times Educational Supplement, May 12, 1972, D. 12.

30 Neal Weeks, A New Look at Chtldren's Sexuallity and Sex Role Identification. U.S., Educational Resources Information Center, ERIC Document ED 097 992, Apr11, 1974, pp. 8-9.

${ }^{4}$ Carole Joffe, "Sex Role Socialization and the Nursery Schools As the Twig Is Bent," Joumal of Namiage and the Family, XXXIII (August, 1971), $467-475$.

Spatricla Minuchin, "The Schooling of Tomorrow"s Women," School Review, LXXX, February, 1972, 200. 
Bowman also stresses the importance of models, the quality of model-child relationships, and the need for models to be clear about what they want to model. 1

Two further suggestions were made by Thetford: including suitable role models representing various life styles in books and exposing occupational opportunities to children from kindergarten to junior high school.2

Howe ${ }^{3}$ and Levy ${ }^{4}$ believe that the most vital force in combatting sexism in the classroom is the teacher. Value clarification strategies and consclousness-raising sessions for teachers and students are helpful in confronting sexist values. In addition to changing classroom practices, teachers should form schoolwide committees to focus on currlcular programs and materials, challenge sex-segregated classes and activities, and gather data on hiring and promotion practices and salaries. 5 The Cedar Rap1ds, Iowa, Community School was one school that signiflcantly changed teacher awareness of sex stereotyping through a series of strategies after recelving a parent complaint about the major reading serles being used in 1973.6

Barbara T. Bowman, "Role-Models and Social Change," Chlldhood Educat1on, LXIX (January, 1973), 180-183.

${ }^{2}$ Mary Thetford, "The Case for the Career Book in Grades Flve to Elght, A Feminist V1ew," Elementary English, L (October, 1973), 10591060.

3owe, p. 81. $\quad 4$ Levy, p. 28.

5evy, p. 29. (1974). 87 .

6Mary Carson, "Action in Cedar Rapids," Today's Education, LXIII 
The Bmma Willard Task Force on Education, an active feminist group, published a book of materials relating to sexlsm in education. ${ }^{1}$ Groups like this one are also conducting workshops and inservice meetings with school employees and parents. Many schools are examining policfea and practices in light of the implementation of Title IX of the Education Amendments Act of 1972.

Career education, thought by many as a vehicle for equalizing opportunities for boys and girls, may instead be perpetuating sex role stereotyping. A recent publication by the Women on Words and Images reports documentation on the extent to which sex role stereotyping was found in an analysis of more than elghty randomly selected kindergarten through $=$ grade-twelve and post-secondary career education materials. Secondly, the report offers general advice to teachers and counselors for detecting and counteracting sexism in classroom materlals. Third, 1t presents a checklist for enriching career opportunity awareness. Finally, the report lists organizations and products which are considered to be nonsexist resources. 2

Mitchell sumnarizes some recommendations for ellminating sex stereotyping through career education:

1) A plan should be developed and implemented in each school for examining the school expertence in order to identify the subtle ways in which girls are belng restrlcted in their achievement by sex stereotypes.

TEmma Willard Task Force on Education, Sexism in Education (Minneapolis: Enma Willard Task Force on Education, 1973). pp. 1-87.

2 Women on Words and Images, Help Wanted, Sexism in Career Education Materlals (Princeton, New Jersey: Women on Words and Images, 1975). $5-49$. 
All teaching materials should be examined for possible

sex discrimination and appropriate steps should be taken to eliminate the discriminatory impact of the material.

2) Workshops and in-service training sessions for teachers should be designed to focus attention on the pervasiveness of sex stereotyping. Deliberate steps should be presented to sensitize teachers and enable then to avoid repetition of the old patterns of expectancies set for both nales and fernales.

3) Change within the curriculum itself should include two aspects: (a) sections about the changing status of women and material from women's studies should be incorporated into the social sclence curriculum and (b) dellberate techniques should be taught to enable teachers to help girls develop instrumental competency. More attention should be Given to girls' use of thought, logie, and probles solving techniques, and less reinforcement should be given to rote memorization and verbal facility. ...

4) Special efforts should be made in the elementary school to draw into the school women who have achieved in various flelds--in science, politics, medicine, etc., who are combining sertous careers with the role of wife and mother.

5) Parent education, focusing on the issue of improving opportunities for the full development of g1rls" potential, should be sponsored by the school as early as kindergarten.

6) High school counselors should be given special professional training for the ellination of discrimination against girls in vocational and educational counseling. 1

While Mitchell's suggestions refer to lessening sex stereotypes for glrls, the importance of freeing boys from rigld sex role stereotypes can also be inferred. Women's 11 beration will increasingly become

$1_{\text {Edna Mitche11, "What About Career Education for Girls?" Educa- }}$ tIonal Leadersh1p. XXX (December, 1972), 235-236. 
a question also of men's Iiberation. In the words of Neugarten:

The questions are 1ikely to be not only how to equalize opportunities for men and women in all areas of life but how to nurture individual differences in both sexes and increase the rewards of Ilfe for all people, no matter how varied their 11 fe styles. 1

\section{SUMMARY}

Preschool and elenentary school children are exploring the type of persons they will become. A leamed sex role directs a ch1ld's behavior, emotional reactions, cognitive funetioning, and general adjusto ment. Parents, teachers, peers, toys, books, and television are important influences on sex role acquisition and preferences. Sex typing of roles, occupational aspirations, and perceptions of occupations begins at a very young age. Appropriate role models, exposure to occupational opportunities, and elimination of sexist attitudes and practlces are needed if both sexes are to be encouraged to develop their interests and abilities in a fast-changing vocational world.

$1_{\text {Bernice L. Neugarten. "Education and the Life-Cycle," School }}$ Revion, LXXX (1972), 213. 


\section{Chapter 3}

\section{RESEARCH DESIGN AND METHODOLOGY}

\section{General Design}

To determine whether boys and girls at different grade levels and from different socio-economic backgrounds held sex role expectations in their stated vocational aspirations and in perceptions of occupations. a standardized intervlew procedure was developed for use with children. A slide-tape presentation of thirty occupations was prepared for inclu sion in the interviews. Professional colleagues were asked to make suggestions about the interview procedure and the slide-tape series depicting occupations. A pilot trial with six children was conducted to test the procedure, the appropriateness of the tape scrlpt, and the wording of the questions. Minor modifications were made before the final tapling of the script, which accompanied the photographs of actual occupational settings.

Permission to carry out the study was secured from the administration of a community school district and from the directors of a day care center and private preschool. Since children would not be identifled by name, school officials decided that parent permission would not be required. However, an information note was written for teachers to send home with their students (Appendix A).

The sample for the study was comprised of 120 children randomly selected from children attending a preschool, a day care center, and second and fifth grades at two elementary schools. Two training and practice sessions for the male-female interview team preceded the data 
collection. Interviews were held during a one-week perlod six weeks before the end of the 1976 academic year.

A twenty-minute interview with each subject in the sample was held in a private room away from the classroom setting. To control for sex bias, two interviewers, both trained in counseling, worked as a female-male team when they were in each school, though each interviewed subjects individually. Bach interviewed half of the boys and half of the girls at each grade level in each school included in the sample. They were trained to use a standardized intervlew procedure (Appendix B) to ask each child about what he/she wanted to do when he/she grew up.

When the vocational aspiration questions were completed, a slidetape presentation of occupations was used to ellcit children's responses to questions about who could work in each of the thirty occupations described. Children's verbal responses to the questions were written on answer sheets. The data generated by the interview questions and responses to the slide-tape presentation were tabulated and analyzed to answer the questions and test the hypotheses posed for the study.

\section{Population and Sample}

The population represented by the study included preschool and elementary school aged chlldren from families whose socio-economic level ranged from upper-lower to upper-middle and who resided in suburban areas near mediun sized cities or metropolitan areas $(75,000-125,000)$ in midwestern United States.

The sample was selected from an Iowa city which has a population of 30,000 and which includes elght neighborhood schools, two juntor high 
schools, and one sentor high school. It is the site of a four-year college, several light industries, and many business concerns. The city adjoins a larger industrialized metropolitan area which has experlenced growth in housing, business, and industry.

Permission to conduct the study in the public schools was granted by the director of elementary education. Only one school in the district was considered to be representative of the lower to lower-midale socioeconomic level; this school was selected for inclusion in the study. The school representing the middle to upper-middle socio-economic level was selected from several possible choices based on the principal's willingness to cooperate. Based on similarity of nelghborhood and backgrounds of chlldren attending, a day care center and a preschool were chosen as matches for the elementary schools.

Comparisons can be made about the familles whose children attend the two neighborhood schools Included in the study. School L (with the I symbolizing the lower to lower-middle level) is located in an area bounded by a mobile home court and homes that can be described as less than affluent. Parents of children attending this school were described by school offlcials as including many "blue collar" workers. In contrast. School $U$ (with the U symbolizing the middle to upper-middle level) is in a newer area of the city having more affluent homes. Parents were described by school officials as including many "white collar" workers. Further information about the schools was derived from a fall, 1975. Title I proposal. In describing the concentration of children from low income families, the district average was 11 sted as 6.5 percent, with School L's average at 23.8 percent and School U's at 1.2 percent. 
Of 486 children in grades kindergarten through sixth at School L, 103 recelved free or reduced hot lunches; at School $v$, the number was only 9 of 386. From October, 1974, to October, 1975, the transfer rates for School I included 14 transfers within the district, 67 to outside the distrlct, and 58 transfers into the school. At School $U$ the transfer data reported were 8 transfers within the district, 32 to outside the district, and 27 into the school. School I was designated as a TItle I school.

Teachers in the school district had developed career education materials in 1973 for use in grades kindergarten through grade six. ${ }^{2}$ Contributors included teachers from both Schools $\mathrm{L}$ and $\mathrm{U}$. Thus it was assumed that children in these schools would have had some exposure to career education concepts. A funior high counselor, assigned to direct the district's career education project, found marked increases in elementary children's career education concepts following a year of career education activities. At the time of the study individual teachers were responsible for any career activities that were incorporated into the curriculum.

Day Care Center L, which w1ll be referred to as Center L, is located directly across the street from School L. It was chosen as a matching center soc10-economically, since it serves the same area of the c1ty as School L, with most children attending School L when they reach school age. Flnancing of this center is through revenue sharing

${ }^{1}$ Cedar Falls Communty Schools, "Career Education in the Elementary Schools" (Cedar Falls, Iowa! Cedar Falls Comuntty Schools, 1973) (Mimeographed). 
funds and County Board of Supervisors' support, as well as through privato fees. A nowly constructed facility, Center L serves fifty children. ranging in age from 2 to 6 and is open from 6,00 a. Preschool $U$, while not located in the exact nelghborhood of School U, was considered an appropriate match since it serves children whose socio-economic background is sinilar to the children attending School U. This private preschool is located in an area of newer homes but also draws chlldren from all over the city, with parents transporting their children. The school director described parents as being of middle to upper-middle economic status with a majority of parents employed in white collar occupations. Tuition for the sixty-six children who attend the two and one-half hour afternoon sessions is $\$ 16$ a month for twice a week or $\$ 24$ a month for three times a week attendance.

The sample for the study was comprised of 120 children--20 from Center L, whose average age was 59 months; 20 from Preschool U, whose average age was 55 months, 40 second graders, half from School L and half from School $U$, whose average age was 100 months and 40 fifth graders, half from School $L$ and half from School U, whose average age was 135 months. A randon numbers table was used to select the subjects=o w1th an equal number of boys and girls in each age group in each school Included in the study--from the 30 four and Plveryear-olds at Center $L$. 66 four and five-year-olds at Preschool U, 62 second graders at School I. 56 second graders at School U, 72 fifth graders at School L, and 63 fifth graders at School U.

\section{Data and Instmumentation}

The data from this study were dram from chlldren's responses 
to a structured interview, which focused on children's vocational aspirations, and from children's responses to a slide-tape presentation deplcting thirty occupations.

To learn about the vocational aspirations of children and to determine whother chlldren held sex role expectations in thelr stated vocational aspirations, children were asked the question, what do you want to be when you grow up?" This format is similar to other studies investigating the vocational interests and aspirations of children. ${ }^{1}$ Intervlewers recorded the responses to the question as well as the age, sex, and the soclo-economic level designated to the school attended by each subject. In addition, the interviewers asked each child, "Have you any other Ideas about what you might want to do?" The answer to this question was also recorded. Including this question made it possible to discover whether children, when given an opportunity, would name more than one occupation. Since career education had been a part of the school curriculum for the older children in the sample, it was considered important to give children an opportunity to name more than one occupation. Occupations named as responses to the question about what a child would like to do were coded by job title and by whether the occupation

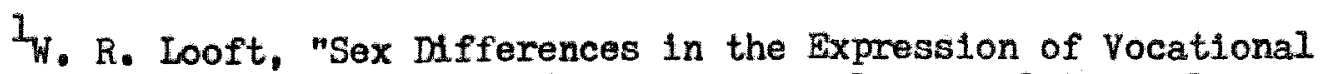
Aspirations by Elementary School Children," Developmental Psychology, V (1971), 366; see also Nancy K. Schlossberg and Jane Goodman, "A Woman's Place: Children's Sex Stereotyping of Occupations, "Vocational Guidance Quarterly, XX (1972), 266-270; Elizabeth P. Kirchner and Sarah I. Vondracek, What Do You Want to Be When You Grow Up? Vocational Cholce in Children Aged Three to Six, U.S. Educational Resources Information Center, BRIC Document ED 076 244, March, 1973, p. 21 Kevin Swick and Mary Ellen Carlton, "An Examination of Occupational Interests of K1ndergarten Children. Implications for Curriculum Development, "Reading Improvement, XI (Spring, 1974), 58=61. 
named was traditionally male, female, or neutral. A second tabulation Included other occupations mentioned by children when asked if there were other things they also might like to do.

To deternine whether chlldren held sex role expectations in their perceptions of occupations, a slide-tape presentation deplcting thirty occupations was developed by this writer. This procedure was a modiflcation of the methodology used in earlier studies of sex-typing of occupa tions. Schlossberg and Coodman used drawings of twelve occupational settings to assess stereotyping by kindergarten and sixth-grade students ${ }^{1}$ They asked children whether a man could work in the setting pletured and If a woman could work there. Pen and ink drawings of people working were used in fulton's study on the vocational development of children, which Included perceptions about sex role expectations of occupations. 2 Those drawings can be criticized for the way in which they perpetuated sex typing of occupations along traditional lines.

In order to alleviate some of the criticisms of earlier studies, thirty occupations were included in the present study--two representing each of the U.S. Offlce of Education's 15 occupational clusters. ${ }^{3}$ This permitted a greater number and varlety of occupations to be depleted than

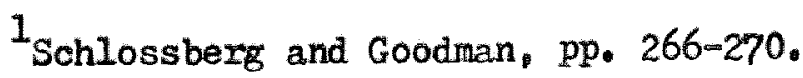

$2^{2}$ Barbara Fulton, "Vocational Development of Children" (unpublished Doctoral dissertation, University of Missouri-Columbla, 1971).

3 State of Iowa, Department of Public Instruction, Models for Career Education in Iowa, Selected Dccupations by Clusters for Use In Elementary Schools (Des Moines, Iowa Department of Public Instruction. 1974), pp. $2-18$. 
the 12 in Schlossberg and Goodman's previous study. ${ }^{1}$ Actual photographs of occupational settings, showing approprlate materials, tools, machines, or background, lent greater realism for assessing children's perceptions. Unlike Fulton's work, these photographs did not show a worker present which could have influenced a respondent to select the sex of the worker shown as the appropriate cholce for an occupation.

In selecting the 30 occupetions to be represented in the study, this writer first 1dentified 60 occupations- -4 from each of the 15 clusters--that preschool and elementary school chlldren would likely be able to understand and relate to via a slide-tape presentation (Appendix C). Both professional and non-professional occupations were included. A balance was provided between occupations usually engaged in by males and those usually engaged in by females as well as inclusion of less well known occupations wth more neutral sex role connotations. Feasibility of taking photographs was another Iimitation in Identifying the pool of 60 occupations.

The 30 occupations in the study were selected from the original 60 identifled by this writer. In order to include a balanced representation of occupations considered as traditionsily male, as traditionally fenale, or more neutral, a panel of 10 independent raters was used to do a Q-sort of the 60 occupations. The raters -5 males and 5 femaleses were professional colleagues of the writer, all of whom had at least a B.A. degree. Each occupation was placed in 1 of 3 categoriesmas being traditionally male, traditionally female, or neutral (Appendix C). A

\footnotetext{
$1_{\text {Schlossberg and Goodman, pp. 266-270. }}$
} 
level of 70 percent agreement was designated as a minimum for considering an occupation to be representative of a female, male, or neutral category.

Using occupations where 70 percent or better agreement was reached by raters, 10 which were considered traditionally female, 10 considered traditionally male, and 10 considered neutral were chosen for inclusion In the slide-tape series. Selection was made so that 2 occupations from each of the 15 occupational clusters were included. Appendix $C$ includes the resulting 30 occupations with proportions of rater agreement.

Following the selection of the occupations, an audio tape scrlpt was prepared, and photographs of the settings were made into a slide series. Suggestions about the descriptions were made by professional colleagues in order to make sure the wording was appropriate for preschool and elementary school children. The Occupational Outlook Handbook and Iowa State Department of Public Instruction's career education materials were consulted in writing the narrative descriptions. ${ }^{1}$ Occupations in the slide-tape series were presented in alphabetical order. The wording of the question following the occupational description read, Who could do the work of a $-2 \operatorname{man}_{0} a$ woman, or both a man and a woman?" for half of the occupations depicted. The order was reversed to read "a woman, a man, or both a woman and a man" for the other half of the occupations. The order of the two versions of the question was randomly used in the narration, with half

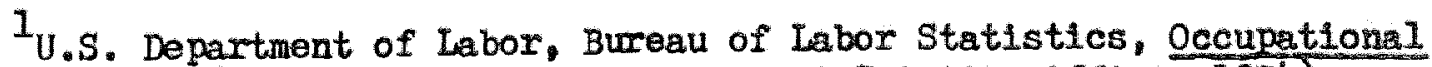
Outlook Handbook (Washington, D.C.: Government Printing Office, 1974) see also State of Iowa, Department of Public Instruction, Models for Career Education in Iowa (Des Molnes, Iowa! Department of Public Instruction, 1971-1975). 
of the descriptions for each of the 3 categorles of occupations-male, female, and neutral--presenting each version. A copy of the tapescript can be found in Appendix $D$.

A pilot trial with 6 children--a boy and a girl at each of these three age levels--preceded the final taping of the script. The pllot trial gave an opportunity to practice the interview procedure to see whether preschool aged children would be able to respond to the slide-tape presentation and to ascertain the appropriateness of the wording of the scrlpt and question. "Who could do the work of a ?" Minor changes in the script were made following the pilot trlal. Children at the three grade levels were able to respond to the interview questions and slide-tape presentation.

The audio-tape description that accompanied the slide photographs was taped twice at a university radio and television studio. One tape was made using a female volce and one with a male volce. The interviewers had coples of both tapes so that half of the girls and half of the boys at each grade level from each school heard the tape with the female volce while the other half heard the tape with the male volce.

Instructions and a trial sample were provided to introduce the slide-tape series, which was presented on a Singer Caramate machine. Then the 30 occupational settings were shown and described. The tape was stopped after each description to write down the subject's response to the question, "Who could do the work of a $--a$ woman, $^{2}$ a man, or both a woman and a man?" A child could have as much time as needed in responding and could choose "I don't know" as an option. The interviewers wrote down the responses to each slide in one of four 
categorles--man, woman, both, or don't know-for later tabulation and analysis.

Anelysis

The questions and hypotheses postulated for this study related to children's sex role expectations in stated vocational aspirations and in perceptions of occupations and the relationship, if any, that could be attributed to sex, grade level, and socio-economic level of the subjects.

The first three questions investigated in the study were $8 \mathrm{~s}$ follows:

1. Do boys and girls differ in the number (varlety) of occupations named as aspirations?

2. Do children at different grade levels differ in the number (variety) of occupations named as aspirations?

3. Do children of different socio-economic levels affer in the number (variety) of occupations named as aspirations?

To answer the preceding questions, children's responses to the Interview questions, "What do you want to be when you grow up?" and "Have you any other ldeas about what you might want to do?" were reported and compared. Frequency distributions were used to report the occupations named as aspirations by each sex, at each grade level, and in each of the two socio-economic levels. The total numbers of specific occupations mentioned by chlldren of each sex at each grade lovel from each of the two soclo-economic levels were tabulated.

Responses were further analyzed in terms of whether the occupations named as asplrations by boys and glrls were sex-typed. A child's response was considered sex-typed when the occupation mentioned as an 
aspiration was traditionally reserved for his/her sex. Occupations named were classified into categories of traditionally male, female, or neutral in keeping with the rater classifications used in selecting occupations for the slide series in the study. Bergmann and Adelman define "komen's" and "men's" occupations as those where the sex has been over-represented in terms of numbers of workers employed. ${ }^{1}$ Schlossberg and Goodman also classified occupations as "feminine" or "masculine" according to the major sex represented in the occupation. ${ }^{2}$ The null hypotheses tested were as follows:

1. Sex-typing of children's vocational aspirations is independent of the sex of the respondents.

2. Sex-typing of children's vocational aspirations is independent of the grade level of the respondents.

3. Sex-typing of children's vocational aspirations is independent of the socio-economic level of the respondents.

Responses to the thirty slide-tape presentation questions, "Who could do the work of a ?" were tabulated for each subject. calculating the number of times a respondent chose "man," "woman," "both," and "don't know." Totals were calculated for analysis by sex, grade level, and socio-economic level of the respondents. The following null hypotheses were tested,

4. Sex role expectations in chlldren's perceptions of occupations

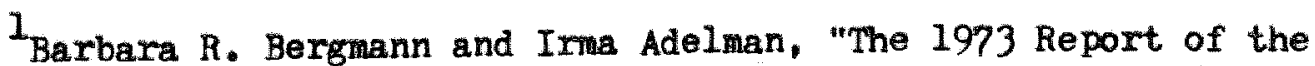
Prosident's Council of Economic Advisors, The Economic Role of Women," The American Economic Review, LXIII (September, 1973), 510-511.

${ }^{2}$ Schlossberg and Coodman, p. 267. 
are independent of the sex of the respondents.

5. Sex role expectations in children's perceptions of occupations are independent of the grade level of the respondents.

6. Sex role expectations in children's perceptions of occupations are independent of the soclo-economic level of the respondents.

Chi-square was chosen as the appropriate statistic for determining independence in testing for significance in hypotheses $1-6$ because of its additive property and usefulness with discrete data in the form of frequencies. A Chi-square significant at the $p=.05$ level was considered adequate to reject a null hypothesis. The computational formula for Chi-square is as follows $t^{1}$

$$
X^{2}=\Sigma\left[\frac{\left(f_{0}-f_{e}\right)^{2}}{f_{e}}\right]
$$

IJ. P. Guilford and Benfamin Fruchter, Fundamental Statistics in Psychology and Education (New York: MeGram-Hili, 1973), p. 199. 


\section{Chapter 4}

\section{FINDINGS}

Interviews with 120 children enrolled in preschool, second grade, and fifth grade were held to determine whether children held sex role expectations in their vocational aspirations and in their perceptions of thirty occupations presented via a slide-tape serles.

The first questions of the study Investigated whether the number (varlety) of occupations named by children differed on the variables of sex, grade level, and socio-econontc level of the respondents.

Occupations named as first-cholce vocational aspirations by sixty boys are shown in a frequency distribution in Table 1. Boys named a total of 29 different occupations. Three preschool boys answered "I don't know" to the question about vocational aspirations. Table 2 shows a com parison of the boys' choices by grade level and economic level. The number of different occupations named as aspirations increased from 8 at the preschool level to 12 at grade two and 15 at grade five. Data from Table 2 do not reveal any definitive trends in the numbers of occupations named by children of the two socio-economic levels.

Table 3 shows the frequency distribution of occupations named as flrst-choice vocational aspirations by sixty girls. Girls named a total of 25 different occupations with the breakdown by grade level and socioaconomic level indleated in Table 4. Seven girls gave "I don't know" as a response. Preschool girls named 9 different occupations as flrst-cholce aspirations, second graders named 10 occupations, and fifth graders named. 12 occupations. 
Table 1

Frequency Distribution of Boys" First-Cholce Occupations Named As Vocational Asplrations By Grade Level and Socio-Economic Level

\begin{tabular}{|c|c|c|c|c|c|c|c|c|}
\hline Occupation & $\begin{array}{l}\text { Classification } \\
\text { into Male, Fe- } \\
\text { male or Neutral }\end{array}$ & Upper & Lower & Upper & Lower & Upper & Lower & $\begin{array}{c}\text { Total } \\
\text { Subjects } \\
\text { Choosing } \\
\end{array}$ \\
\hline 1. Truck Drtver & M & 1 & 2 & & 1 & 1 & 1 & 6 \\
\hline 2. Pollceman & M & 4 & & 1 & 1 & 3 & & 9 \\
\hline 3. Fireman & M & 1 & 3 & & 3 & & & 7 \\
\hline 4. Doctor & $M$ & 1 & 1 & & & & & 2 \\
\hline 5. Train Engineer & $\mathrm{M}$ & & 1 & & & & & 1 \\
\hline 6. Football Player & M & & 1 & & & & & 1 \\
\hline 7. Run Doughnut Shop & $\mathrm{N}$ & & 1 & & & & & 1 \\
\hline 8. John Deere Worker & $M$ & & 1 & 1 & 2 & & & 4 \\
\hline 9. Race Car Driver & $M$ & & & 2 & & & & 2 \\
\hline 10. Cement Horker & $M$ & & & 1 & & & & 1 \\
\hline 11. Basketball Player & M & & & 1 & & & & 1 \\
\hline 12. Welder & $M$ & & & 1 & 2 & & & 3 \\
\hline 13. Electrician & M & & & 1 & & & & 1 \\
\hline 14. Gas Station Attendent & $\mathrm{M}$ & & & 1 & & & & 1 \\
\hline 15. Store Manager & M & & & 1 & & & & 1 \\
\hline 16. Rancher & $\mu$ & & & & 1 & & & 1 \\
\hline 17. Mechanic & $M$ & & & & & 1 & & 1 \\
\hline 18. Sclentist & $\mathbb{N}$ & & & & & 1 & & 1 \\
\hline
\end{tabular}


Table 1 (Continued)

\begin{tabular}{|c|c|c|c|c|c|c|c|c|}
\hline \multirow[b]{2}{*}{ Occupation } & \multirow{2}{*}{$\begin{array}{l}\text { Clsssification } \\
\text { into Male, Fe- } \\
\text { male or Neutral }\end{array}$} & \multicolumn{2}{|c|}{ Preschool } & \multicolumn{2}{|c|}{ Grade 2} & \multicolumn{2}{|c|}{ Grade 5} & \multirow{2}{*}{$\begin{array}{l}\text { Total } \\
\text { Subjects } \\
\text { Choosing }\end{array}$} \\
\hline & & Upper & Lower & Upper & Lower & Upper & Lower & \\
\hline $\begin{array}{l}\text { 19. Grocery Carry Out } \\
\text { 20. Lawyer } \\
\text { 21. Pharmacist } \\
\text { 22. Bowling Alley Manager } \\
\text { 23. Pilot } \\
\text { 24. Baby Sitter } \\
\text { 25. Farmer } \\
\text { 26. Preacher } \\
\text { 27. Marine Blologist } \\
\text { 28. Detective } \\
\text { 29. Motor Cycle Racer } \\
\text { Don't Know }\end{array}$ & $\begin{array}{l}M \\
M \\
M \\
M \\
F \\
M \\
M \\
N \\
M \\
M \\
-\end{array}$ & 3 & & & & $\begin{array}{l}1 \\
1 \\
1 \\
1\end{array}$ & $\begin{array}{l}2 \\
1 \\
1 \\
1 \\
1 \\
1 \\
1\end{array}$ & $\begin{array}{l}1 \\
2 \\
1 \\
1 \\
2 \\
1 \\
1 \\
1 \\
1 \\
1 \\
1 \\
3\end{array}$ \\
\hline Totals & & 10 & 10 & 10 & 10 & 10 & 10 & 60 \\
\hline
\end{tabular}


Table 2

Number of Different Occupations Named As

First-Cholce Asplrations By Boys

\begin{tabular}{lcccc}
\hline & \multicolumn{2}{c}{ Socio-Economic Level } & & \\
Grade Level & Upper & Lower & Total & Don't Know \\
\hline Preschool & 4 & 7 & 8 & 3 \\
Grade 2 & 9 & 6 & 12 & 0 \\
Grade 5 & 8 & 9 & 15 & 0 \\
Totals & & & 29 & 3 \\
\hline
\end{tabular}

* Totals reflect overlap in responses made by respondents at the two socio-economic levels.

Table 5 shows the comparison of responses by boys and girls at the two soclo-economic levels. The $30 \mathrm{glrls}$ from upper socio-economic level schools named 16 different occupations, while the $30 \mathrm{girls}$ from lower socio-economic level schools named 13 different occupations. This compared w1th 18 different occupations that were nemed as first-cholce aspirations by the 30 boys at each of the two socio-economic levels. While the trend is not a large one, boys at both sociomeconomic levels named a greater number of occupations as aspirations than did girls. With boys of the two levels nominating equal numbers (18) of occupations as aspirations, girls from the upper socio-economic level nominating 16, and girls from the lower soclo-econonic level naming 13 , any trends Indicated by this study on the varlable of socto-economic level seem to be small and applicable to firls only. 
Table 3

Frequency Distribution of Girls" First-Cholce Occupations Named As Vocational Aspirations By Grade Level and Socio-Economic Level

\begin{tabular}{|c|c|c|c|c|c|c|c|c|}
\hline \multirow[b]{2}{*}{ Occupation } & \multirow{2}{*}{$\begin{array}{l}\text { Classification } \\
\text { into Male, Fe- } \\
\text { nale or Neutral }\end{array}$} & \multicolumn{2}{|c|}{ Preschool } & \multicolumn{2}{|c|}{ Grade 2} & \multicolumn{2}{|c|}{ Grade 5} & \multirow{2}{*}{$\begin{array}{l}\text { Total } \\
\text { Subjects } \\
\text { Choosing }\end{array}$} \\
\hline & & Upper & Lower & Upper & Lower & Upper & Lower & \\
\hline 1. Nurse & $\mathbf{F}$ & 2 & 2 & 5 & 2 & 1 & 2 & 14 \\
\hline 2. Ballerina & $F$ & 1 & & & & & & 1 \\
\hline 3. B1ke R1der & N & 1 & & & & & & 1 \\
\hline 4. Letter Writer & N & 1 & & & & & & 1 \\
\hline 5. Mother & $F$ & 2 & 1 & & & & & 3 \\
\hline 6. Truck Driver & M & & 1 & & & & & 1 \\
\hline 7. Horse Trainer & M & & 1 & & 2 & & 1 & 4 \\
\hline 8. Cowgirl & $\mathrm{F}$ & & 1 & & & & & 1 \\
\hline 9. Wonderwoman & $\mathrm{F}$ & & 1 & & & & & 1 \\
\hline 10. Dairy Store Worker & $\mathbb{N}$ & & & 1 & & & & 1 \\
\hline 11. Axtist & $\mathrm{N}$ & & & 2 & & & & 2 \\
\hline 12. Deputy of the Court & $\mathrm{N}$ & & & 1 & & & & 1 \\
\hline 13. Veternarian & M & & & 1 & 1 & & 3 & 5 \\
\hline 14. Teacher & $\mathrm{F}$ & & & & 2 & 1 & 1 & 4 \\
\hline
\end{tabular}


Table 3 (Continued)

\begin{tabular}{|c|c|c|c|c|c|c|c|c|}
\hline \multirow[b]{2}{*}{ Occupetion } & \multirow{2}{*}{$\begin{array}{l}\text { Classification } \\
\text { into Pale, Fe- } \\
\text { male or Neutral }\end{array}$} & \multicolumn{2}{|c|}{ Preschool } & \multicolumn{2}{|c|}{ Grade 2} & \multicolumn{2}{|c|}{ Grade 5} & \multirow{2}{*}{$\begin{array}{l}\text { Total } \\
\text { Subjects } \\
\text { Choosing }\end{array}$} \\
\hline & & Upper & Lower & Upper & Lower & Upper & Lower & \\
\hline 15. Madd & $F$ & & & & 1 & & & 1 \\
\hline 16. Storekeeper & $\mathrm{N}$ & & & & 1 & & & 1 \\
\hline 17. Kousewife & $F$ & & & & 1 & & & 1 \\
\hline 18. Interior Designer & N & & & & & 1 & & 1 \\
\hline 19. AlrIine Stewardess & F & & & & & 2 & & 2 \\
\hline 20. Lawyer & M & & & & & 2 & & 2 \\
\hline 21. Beautician & $F$ & & & & & 1 & & 1 \\
\hline 22. Secretary & F & & & & & 1 & & 1 \\
\hline 23. Gymnist & $\mathbb{N}$ & & & & & 1 & & 1 \\
\hline 24. Orthodontist & M & & & & & & 1 & 1 \\
\hline 25. Doctor & $M$ & & & & & & 1 & 1 \\
\hline Don"t know & - & 3 & 3 & & & & 1 & 7 \\
\hline Totals & & 10 & 10 & 10 & 10 & 10 & 10 & 60 \\
\hline
\end{tabular}


Table 4

Number of Different Occupations Named As

Flrst-Cholce Aspirations By Girls

\begin{tabular}{|c|c|c|c|c|}
\hline \multirow[b]{2}{*}{ Grade Level } & \multicolumn{2}{|c|}{ Socio-Economic Level } & \multirow[b]{2}{*}{$\operatorname{Total}{ }^{*}$} & \multirow[b]{2}{*}{ Don ${ }^{\circ} t$ Know } \\
\hline & Upper & Lower & & \\
\hline Preschool & 5 & 6 & 9 & 6 \\
\hline Grade 2 & 5 & 7 & 10 & 0 \\
\hline Grade 5 & 8 & 6 & 12 & 1 \\
\hline Total & & & 25 & 7 \\
\hline
\end{tabular}

* Totals reflect overlap in responses made by respondents at the two socio-economic levels.

\section{Table 5}

Comparisons of the Numbers of Different Occupations

Named As Furst-Choice Aspirations By Children

Attending Two Socio-Economic Level Schools

\begin{tabular}{|c|c|c|c|}
\hline \multirow{2}{*}{$\begin{array}{l}\text { Sex of } \\
\text { Respondents }\end{array}$} & \multicolumn{2}{|c|}{ Soclo-Economic Level } & \multirow{2}{*}{$\begin{array}{l}\text { Total Number of } \\
\text { Occupations Named }\end{array}$} \\
\hline & Upper & Lower & \\
\hline G1rls & 16 & 13 & 25 \\
\hline Boys & 18 & 18 & 29 \\
\hline
\end{tabular}

* Totals reflect overlap in responses made by respondents at the two socio-economic levels.

Children were also given an opportunity to give a second choice to the question about what they would like to be when they grow up. Boys" second choices are 1isted on a frequency distribution in Table 6. The boys named a total of 20 occupations, w1th 23 responding. "I don"t know." 
Table 6

Frequency Distribution of Boys" Second-Cholce Occupations Named As Vocational Aspirations By Grade Level and Socio-Economic Level

\begin{tabular}{|c|c|c|c|c|c|c|c|c|}
\hline \multirow[b]{2}{*}{ Occupation } & \multirow{2}{*}{$\begin{array}{l}\text { Classification } \\
\text { into Male, Fe- } \\
\text { male or Neutral }\end{array}$} & \multicolumn{2}{|c|}{ Preschool } & \multicolumn{2}{|c|}{ Grade 2} & \multicolumn{2}{|c|}{ Grade 5} & \multirow{2}{*}{$\begin{array}{l}\text { Total } \\
\text { Subjects } \\
\text { Choosing }\end{array}$} \\
\hline & & Upper & Lower & Upper & Lower & Upper & Lower & \\
\hline $\begin{array}{l}\text { 1. Tractor Shovel } \\
\text { Operator }\end{array}$ & M & 1 & & & & & & 1 \\
\hline 2. Pollceman & M & 1 & 2 & 2 & 1 & & & 6 \\
\hline $\begin{array}{l}\text { 3. Service--Arny, Navy } \\
\text { or Marine }\end{array}$ & $M$ & 1 & & & & & 2 & 3 \\
\hline 4. What My Dad Is & $M$ & & 1 & & & & & 1 \\
\hline 5. Cartoonist & $\mathbf{N}$ & & & 1 & & & & 1 \\
\hline 6. Truck Driver & $M$ & & & 3 & 1 & 1 & & 5 \\
\hline 7. Football Player & M & & & 1 & 2 & 1 & & 3 \\
\hline 8. Electrician & M & & & 1 & & & & 1 \\
\hline 9. Pilot & M & & & 1 & 1 & & & 2 \\
\hline 10. Garbage Collector & $M$ & & & & 1 & & & 1 \\
\hline 11. F1 reman & $M$ & & & & 1 & & & 1 \\
\hline 12. John Deere Worker & $M$ & 1 & & & 1 & 1 & 1 & 4 \\
\hline
\end{tabular}


Table 6 (Continued)

\begin{tabular}{|c|c|c|c|c|c|c|c|c|}
\hline \multirow[b]{2}{*}{ Dccupation } & \multirow{2}{*}{$\begin{array}{l}\text { Classiflcation } \\
\text { into Male, Fe- } \\
\text { male or Neutral }\end{array}$} & \multicolumn{2}{|c|}{ Preschool } & \multicolumn{2}{|c|}{ Grade 2} & \multicolumn{2}{|c|}{ Grade 5} & \multirow{2}{*}{$\begin{array}{l}\text { Total } \\
\text { Subjects } \\
\text { Choosing }\end{array}$} \\
\hline & & Upper & Lower & Upper & Lower & Upper & Lower & \\
\hline 13. Construction Worker & $M$ & & & & & 1 & & 1 \\
\hline 14. Coach & M & & & & & 1 & & 1 \\
\hline 15. Engineer & $M$ & & & & & 1 & & 1 \\
\hline 16. Race Car Drtver & $\mathbf{M}$ & & & & & & 1 & 1 \\
\hline 17. Carpenter & M & & & & & & 1 & 1 \\
\hline 18. Detective & $M$ & & & & & & 1 & 1 \\
\hline 19. Ut1lit1es Worker & M & & & & & & 1 & 1 \\
\hline 20. Computer Worker & $\mathbf{N}$ & & & & & & 1 & 1 \\
\hline Don't Know & - & 6 & 7 & 1 & 3 & 4 & 2 & 23 \\
\hline Totals & & 10 & 10 & 10 & 10 & 10 & 10 & 60 \\
\hline
\end{tabular}


Table 7 indicates the breakdown by grade level and by soclo-economic level. A total of 5 different occupations were named as second-choice aspirations by the preschoolers, 9 by second graders, and 12 by fifth graders.

\section{Table ?}

Number of Different Occupations Named As Second-Choice Aspirations By Boys

\begin{tabular}{lcccc}
\hline & \multicolumn{2}{c}{ Socio-Economic Level } & \\
Grade Level & Upper & Lower & Total $^{*}$ & Don't Know \\
\hline Preschool & 4 & 2 & 5 & 13 \\
Grade 2 & 6 & 7 & 9 & 4 \\
Grade 5 & 6 & 7 & 12 & 6 \\
\hline Total & & & 20 & 23 \\
\hline
\end{tabular}

* Totals reflect overlap in responses made by respondents at the two socio-economic levels.

Table 8 summarlzes the girls' second-choice occupations named as aspirations. The sixty girls named a total of 15 different occupations. Twenty-s1x glxls gave "I don't know" as a response. Table 9 shows that preschool girls named 5 different occupations as second-choice aspirations, second graders named 7 , and fifth graders named 9.

Table 10 shows the comparlsons in the total numbers of occupations named as second-choice aspirations by children attending the two socio economic level schools. Girls from upper sociomeconomic level schools named 10 occupations to 8 by the girls from lower sociomeconomic level schools. Boys at the upper level schools named 12 occupations, while boys 
Table 8

Frequency Distribution of Girls' Second-Choice Occupations Named As Vocational Aspirations By Grade Level and Soclo-Economic Level

\begin{tabular}{|c|c|c|c|c|c|c|c|c|}
\hline \multirow[b]{2}{*}{ Occupation } & \multirow{2}{*}{$\begin{array}{l}\text { Classification } \\
\text { into Male, Fe- } \\
\text { male or Neutral }\end{array}$} & \multicolumn{2}{|c|}{ Preschool } & \multicolumn{2}{|c|}{ Grade 2} & \multicolumn{2}{|c|}{ Grade 5} & \multirow{2}{*}{$\begin{array}{l}\text { Total } \\
\text { Subjects } \\
\text { Choosing }\end{array}$} \\
\hline & & Upper & Lower & Upper & Lower & Upper & Lower & \\
\hline 1. Pom-Pon Girl & F & 1 & & & & & & 1 \\
\hline 2. Sew Things & $F$ & 1 & & & & & & 1 \\
\hline 3. Teacher & $\mathbf{F}$ & & 1 & 3 & 1 & 4 & 2 & 11 \\
\hline 4. Ballerina & $\mathbf{F}$ & & 1 & & & & & 1 \\
\hline 5. Cook & $F$ & & 1 & & 1 & 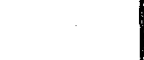 & 1 & 3 \\
\hline 6. Nurse & $\mathbf{F}$ & & & 2 & 2 & 1 & & 5 \\
\hline 7. Telephone Operator & $F$ & & & 1 & & & & 1 \\
\hline 8. Horse RIder & 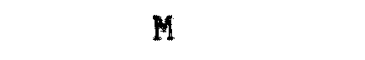 & & & 1 & & & & 1 \\
\hline 9. Doctor & M & & & 1 & & & & 1 \\
\hline 10. Secretary & F & & & & 1 & 2 & 1 & 4 \\
\hline 11. Interior Designer & $\mathbf{N}$ & & & & & 1 & & 1 \\
\hline 12. Muslcian & $\mathrm{N}$ & & & & & 1 & & 1 \\
\hline 13. Stewardess & $\mathbf{F}$ & & & & & & 1 & 1 \\
\hline 14. Lion Tamer & M & & & & & & 1 & 1 \\
\hline 15. Theket Taker & N & & & & & & 1 & 1 \\
\hline Don't Know & - & 8 & 7 & 2 & 5 & 1 & 3 & 26 \\
\hline Totals & & 10 & 10 & 10 & 10 & 10 & 10 & 60 \\
\hline
\end{tabular}


at the lower level schools named 14. The difference of only 2 by both sexes is probably too small to suggest a trend on the variable of socioeconomic level.

Table 9

Number of Different Occupations Named As Second-Cholce Aspirations By Girls

\begin{tabular}{lcccc}
\hline & \multicolumn{2}{c}{ Socio-Economic Level } & \\
Grade Level & Upper & Lower & Total $^{*}$ & Don't Know $^{\text {'t }}$ \\
\hline Preschool & 2 & 3 & 5 & 15 \\
Grade 2 & 5 & 4 & 7 & 7 \\
Grade 5 & 5 & 6 & 9 & 4 \\
& & & 15 & 26 \\
\hline
\end{tabular}

* Totals reflect overlap in responses made by respondents at the two socio-economic levels.

Table 10

Conpartsons of the Numbers of Different Occupations

Named As Second-Choice Aspirations By Children

Attending Two Soclo-Economic Level Schools

\begin{tabular}{cccc}
\hline $\begin{array}{c}\text { Sex of } \\
\text { Respondents }\end{array}$ & $\begin{array}{c}\text { Socio-Economic Level } \\
\text { Upper }\end{array}$ & Lower & $\begin{array}{c}\text { Total Nuber of } \\
\text { Occupations Naned }\end{array}$ \\
\hline G1rls & 10 & 8 & 15 \\
Boys & 12 & 14 & 20 \\
\hline
\end{tabular}

* Totals reflect overlap in responses by respondents from the two socio-economic levels.

The reported findings can be used to answer the first threo questlons posed for the study. Boys and girls were found to differe in 
the number (varlety) of occupations named as aspirations, with boys naming a greater number of different occupations in both first and second cholces. The second question dealt with differences in occupations stated as aspirations on the variable of grade level of respondents. For both boys and for girls the trend was for the number of occupations named as aspirations to increase with the age level of the children.

Findings did not indicate any major trends in differences on the varlable of socio-economic level of respondents, which was the variable considered by the third question of the study.

The first cholces that chlldren named as vocational aspirations were further analyzed in terms of sex-typing. Chi-square was used to test for Independence of the variables of sex, grade level, and socioeconomic level of respondents on sex-typing of occupations named as aspirations.

Occupations named as aspirations were classifled into categories of traditionally male, traditionally female, and neutral. The classificat1ons concurred with the ratings made by the raters when occupations were categorized for the slide serles. The occupational classifications are included in the frequency distributions reported in Tables 1 and 3.

The first null hypothesis of the study was as follows sex-typing of chlldren's vocational aspirations is independent of the sex of the respondents. Table 11 reports the Chi-square contingency table which Indicates $\chi^{2}=54.42, p<.001$. Boys chose traditional male occupations as aspirations almost exclusively. Only 1 boy named a traditionally female occupation, and only 3 named occupations classified as neutral. Half the girls named traditional female occupations, but girls also named 14 
traditional male occupations as choices and 9 occupations classified as neutral. Based on these findings, the null hypothesis was rejected.

Table 11

Contingency Table Showing Relationship of Sex-Typing in

First-Choice Aspirations and Sex of Respondents

\begin{tabular}{|c|c|c|}
\hline \multirow{2}{*}{$\begin{array}{l}\text { Sex-Typed } \\
\text { Classification } \\
\text { of Occupation }\end{array}$} & \multicolumn{2}{|c|}{ Selections by Sex } \\
\hline & Boys & Girls \\
\hline Male & 53 & 14 \\
\hline Fenale & 1 & 30 \\
\hline Neutral & 3 & 9 \\
\hline Don't Know & 3 & 7 \\
\hline & $\begin{array}{l}N=60 \\
X^{2}=5\end{array}$ & $\begin{array}{l}=60 \\
.001\end{array}$ \\
\hline
\end{tabular}

Table 12 indicates that there is no significant relationship between grade level and sex-typing in named aspirations. The null hypothesis that sex-typing of children's rocational aspirations is independent of the grade level of the respondents was retalned. The differences between responses of children at different grade levels were not significant $\left(\chi^{2}-1.39, p<.80\right)$. 
Table 12

Contingency Table Showing Relationsh1p of Sex-Typing in FIrst-

Choice Asplrations and Grade Lovel of Respondents

\begin{tabular}{|c|c|c|c|}
\hline \multirow{2}{*}{$\begin{array}{l}\text { Sex-Typed } \\
\text { Classification } \\
\text { of Occupation }\end{array}$} & \multicolumn{3}{|c|}{ Selections by Grade Level } \\
\hline & Preschool & Grade 2 & Grade 5 \\
\hline Male & 18 & 24 & 25 \\
\hline Female & 11 & 11 & 10 \\
\hline Neutral & 2 & 5 & 4 \\
\hline & $\begin{array}{l}N=31 * \\
X^{2}=1 \cdot 3\end{array}$ & $\begin{array}{l}=40 \\
<.80\end{array}$ & $N=39 *$ \\
\hline
\end{tabular}

*Totals do not equal 40 because of "don"t know" responses.

The third hypothesis was that sex-typing of children's vocational aspirations is independent of the socio-economic level of the respondents. Table 13 indicates that the hypothesis was retained. More lower soc10economic level respondents did choose traditional male occupations as cholces. However, differences were not significant, as indicated by the findings $\left(X^{2}=4.64, p<.20\right)$.

Responses to the thirty slide-tape presentation questions, "Who could do the work of a ?" were analyzed by sex, grade level. and soolo-economic level of the respondents to test the final three null hypotheses. The number of tines each chlld responded with man, woman. both, and don't know was calculated. Then the responses could be added to test the hypotheses. 
Table 13

Contingency Table Showing Relationship of Sex-Typing in FirstChoice Asplrations and Soclo-Economic Level of Respondents

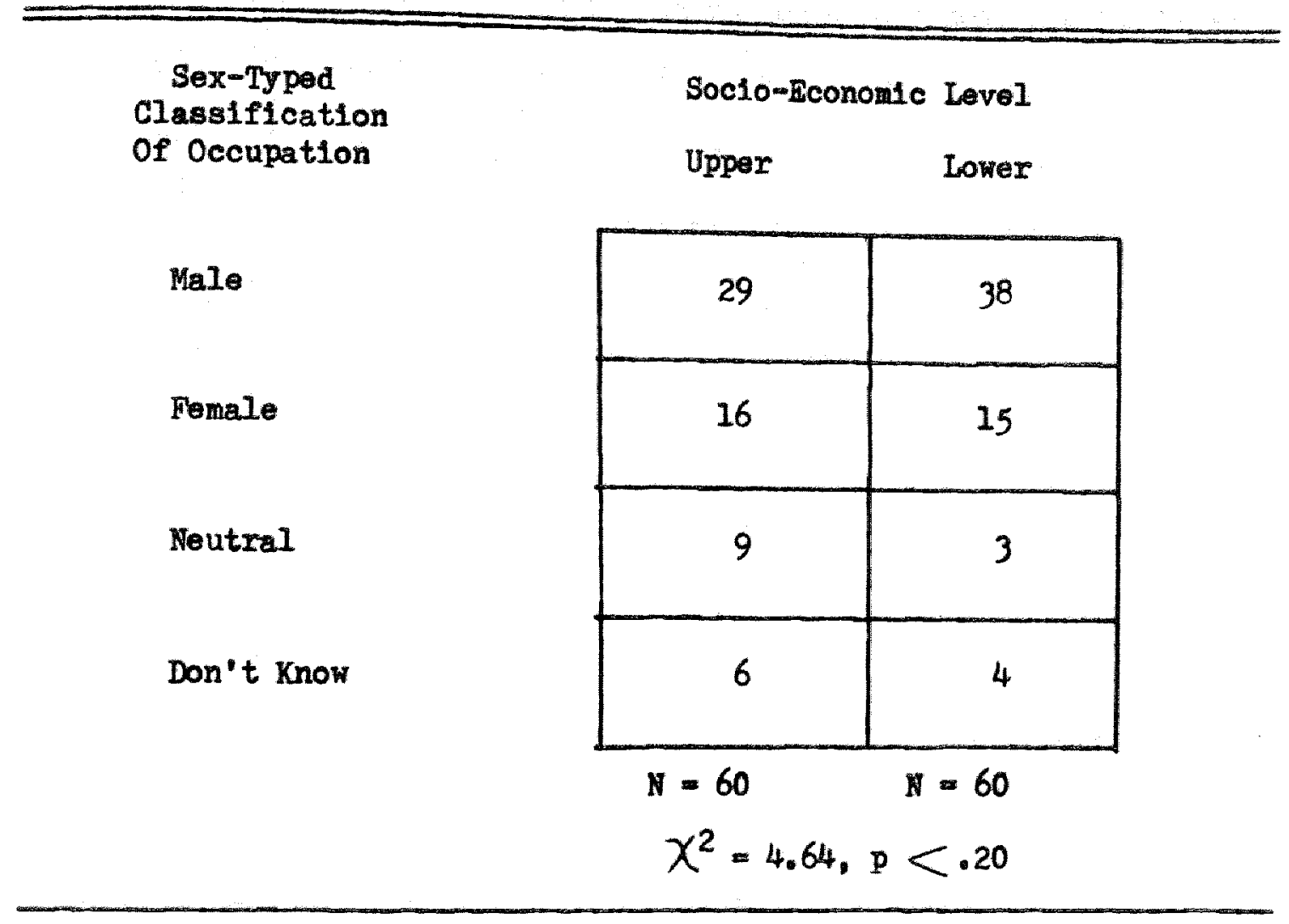

Table 14 is the contingency table used to test the null hypothesis that sex role expectations in chlldren's perceptions of occupations are Independent of the sex of the respondents.

Findings reject the null hypothesis at the .01 level of signiflcance $\left(\chi^{2}=12.62\right)$, Indlcating that there 18 a relationship between sex role expectations in perceptions of occupations and the sex of the respondents. A greater number of girls than boys chose "woman" as a choice Por who could do the work in the occupations depicted, wh1le srester number of boys than girls chose "man" as someone who could do that work. Both boys and girle chose "man" wore frequently than oven the girls chose "woman." Boys chose "neutral" more frequently than did olrls for 
the occupations shown. Six more glrls than boys responded with "don't know." Results indicate that a majorlty of both boys and girls percelved the thirty occupations as noutral places where both a man and a woman could work. When occupations were not considered as places where both a man and a woman could work, the occupations were more often percelved as for men, as indicated by the data that "man" was chosen 955 times compared with the response of "woman" made 737 times.

Table 14

Cont1ngency Table Showing Relationship of Sex Role Perceptions of 30 Occupations and Sex of Respondents

Total Cholces of Who Could Do the Work in 30 Occupations

Woman

Man

Both

Don't Know
Sex of Respondents

Boys Girls

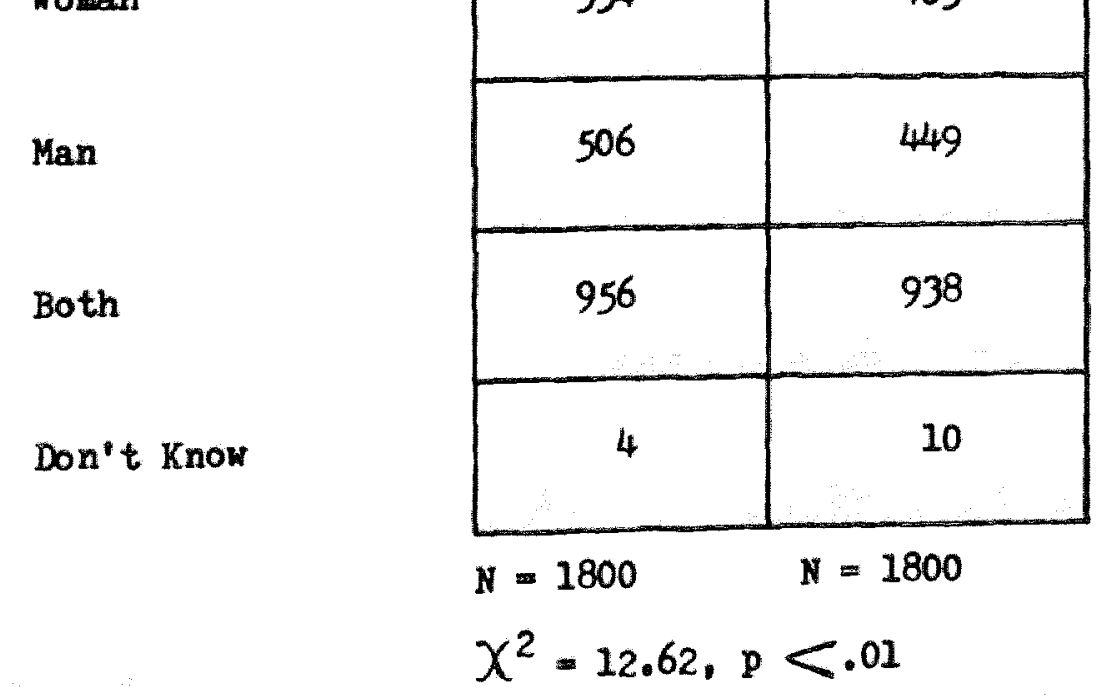

The null hypothesis that sex role expectations in perceptions of occupations 18 independent of the grade level of the respondents was also 
re jected by the findings of this study. Table 15 indicates the relationship of the cholces made by children at the three grade levels $\left.\chi^{2}=146.52, \mathrm{p}<.001\right)$.

Table 15

Contingency Table Showing Relationship of Sex Role Perceptions of 30 occupations and Grade Level of Respondents

Total Choices of Who Could Do the Work in 30 Occupations

Woman

Man

Both
Grade Level of Respondents

Preschool Grade $2 \quad$ Grade 5

\begin{tabular}{|c|c|c|}
\hline 307 & 217 & 213 \\
\hline 410 & 320 & 225 \\
\hline 470 & 663 & 761 \\
\hline$N=1187^{*}$ & $N=1200$ & $N=1199 *$ \\
$X 2=146.52, P<.001$ &
\end{tabular}

* Totals for the three grade levels do not total 1200 each because of "don"t know" responses of 13 preschoolers and 1 fifth grader. These were dropped from the table.

Results indicate that as age level increased, cholces became less sex-typed, and occupations were more 11kely to be viewed as places where both a woman and a man could work. Preschool children chose "woman" and "man" wore frequently as responses than respondents at the other two grade levels. With increasing grade level, children chose "both" with greater frequency. A majortty of the responses did favor "both" (1894). 
with "man" recelving a total of 955 responses and "woman" 737 responses.

The last null hypothesis of the study was that sex role expectations in children's perceptions of occupations are independent of the socio-economic level of the respondents. Table 16 indicates that the differences on the variable of socio-economic level are significant $\left(X^{2}=9.36, p<.05\right)$, thus rejecting the null hypothesis.

Table 16

Contingency Table Showing Relationship of Sex Role Perceptions of 30 Occupations and SocioEconomic Level of Respondents

Total Cholces of Who Could Do the Work in 30 Occupetions

Woman

Man

Both

Don't Know
Socto-Economic Level

Upper Lower

\begin{tabular}{|c|c|}
\hline 339 & 398 \\
\hline 467 & 488 \\
\hline 985 & 909 \\
\hline 9 & 5 \\
\hline
\end{tabular}

$N=1800 \quad N=1800$

$\chi^{2}=9.36, \mathrm{p}<.05$

A greater number of children attending the lower socio-economie level schools than children attending upper soclo-economic level schools chose "man" and "woman" as responses, indicating greater sex-typing in 
sex role perceptions of occupations. A greater number of upper level chlldren chose "both" as a response, but "both" was chosen by a majority of children at each of the two sociomeconomic levels,

\section{SUMHARY OF ETNDTMCS}

The flrst three questions of the study compared the number (varlety) of occupations nawed as asplrations on the vartables of sex. grade level, and socio-economic status of respondents. FIndings were reported on frequency distributions for boys and for giris. While differences were not large, the number (varlety) of occupations named by chlldren as aspirations did differ on the varlables of sex and grade levels. Boys named a greater number of occupations than girls in both first and second choices. As grade level increased, the number of first and second-cholce occupations named as aspirations also increased. Findings did not reveal differences on the vartable of socioeconoalc level for boys and only small variations for girls.

Further analysis of the stated aspirations of children rejected the first null hypothesis of the study-that sex-typing of children's vocationel aspirations is independent of the sex of the respondents. Boys chose a higher number of sex-typed occupations, excluded women from occupations wore than girls did, and chose fewer "neutral" occupa" tions as aspirations. Girls' cholces also reflected sex-typing but to a seeningly lesser degree.

Findings did not show significant differences on the varlables of grade level and soclo-economic level. Therefore, the two null hypotheses postulating independence of these variables in sex-typing 
of children's vocational aspirations were retained. Analysis of the responses to the slide-tape series of thirty occupational settings rejected the null hypotheses that sex role expectations in children's perceptions of occupations were independent of the variables of sex, grade level, and socio-economic level. A majority of both sexes chose "both" as being able to do the work in the occupations, but "man" was chosen more frequently than "woman" as someone who could do the work in the occupations shown. With increasing age, a greater number of children selected "both" as a cholce, revealing less sex-typing in expectations of who could do the work. Children attending the lower soclo-economic level schools revealed more sextyping in perceptions of occupations than their upper socio-economic level counterparts. 
Chapter 5

DISCUSSION, CONCLUSIONS, AND RECOMMENDATIONS

The Problem

The purpose of this study was to determine whether children held sex role expectations in theix stated vocational asplrations and in their perceptions of occupations. In addition, the differences in responses between boys and glrls; between preschool, lower elementary, and upper elementary school children; and between children attending schools in two neighborhoods--one predominantly lower to lower-middle class, the other middle to upper-middle class--were calculated and analyzed.

\section{Discussion}

Sex-typing in vocational aspirations of young children was Indicated in both the number (varlety) of occupations named as aspirations by boys and girls in the study as well as in the way these occupa tions conformed to traditional sex roles. However, comparisons of the findings of this study with previous findings suggest that a lessening In sex-typing of aspirations may be occurring. Studies by Looft, ${ }^{1}$ Hewltt, ${ }^{2}$ Hahn, ${ }^{3}$ and Swlck and Carlton ${ }^{4}$ all

1W. R. Looft, "Sex Differences in the Expression of Vocational Aspirations by Elementary School Children," Developmental Psychology. $V(1971), 366$.

${ }^{2}$ Lymn Stewart Hewtt, "Age and Sex Differences in the Vocatlonal Aspirations of Elenentary School Children," Journal of Soclal Psychology. XCVI (1975), 175.

3 Carol Hahn, "The Me I Want to Bet Students' Aspirations in the Sevent1es," Soclal Education, XXXVIII (Apri1, 1974), 341.

4 Kevin J. Swick and Mary Ellen Carlton, "An Examination of Occupational Interests of Kindergarten Children, Implications for Curriculum Development," Reading Improvement, XI (Spring, 1974), 59-60. 
reported that boys nominated a greater number of occupations as aspirations than girls did. Findings of the present study show that the sixty boys named 29 different occupations with policeman (9), fireman (7), truck driver (6), and John Deere Worker (4) as most popular choices. The sixty girls named 25 different occupations with most frequentiy named first-choice aspirations being nurse (14), vetemarian (5), horse trainer (4), teacher (4), and mother (3).

Children named a wide diversity of occupations as aspirations, Indicative of the awareness and accommodation stages of career development. The number of different occupations named by children at each grade level increased with each higher grade level. With increasing age, both boys and girls percelved their job perspectives as broadening. This is a contrasting finding to that of Hewitt, who found that girls chose only a few vocational alternatives, primarily nursing and teaching. ${ }^{1}$ Including preschool children in the sample allowed comparison with other studies of kindergarten and lower elementary children. The 40 preschool boys named 8 occupations as aspirations, while the 40 girls named 9. Sw1ck and Carlton reported 24 k1ndergarten boys nominated 16 occupations, and 24 kindergarten girls named 9. Looft's study reported first and second-grade boys named 18, girls 8 . Comparisons suggest that the disparity between number of different occupations named by boys and girls occurs sometime between preschool and kindergarten or first grade. Preschool boys' cholces centered around community workers, who are readily observable as role models. Girls' choices also reflected

$$
\text { Hewitt, p. } 176 .
$$


observable role models (nurse, mother), as well as fantasy models (ballerina, Wonderwoman, cowg1rl).

Nelther the lower nor upper-elementary children (grades two and five) in the present study named as many different occupations as asplrations as other studies have reported. No important differences were found in the number of different occupations named as asplrations by children of the middle to upper-middle class compared with children of the lower to lower-midale class. Boys in each of the two classes nominated 18 occupations, while upper to upper-middle class girls named 16 and lower to lower-middle class girls, 13.

Second choices of occupational aspirations revealed that nearly half of both boys and girls responded "I don't know." While this might have been expected at the preschool level, the fact that $10 \mathrm{fifth}$ graders also made this cholce might Indicate that children may not be aware of a number of vocational cholces. Aspirations appear to be falrly well crystallized into one cholce. Boys named a total of 20 different occupatlons as second cholces, with policeman (6), truck driver (5), and John Deere Worker (4) as popular cholces. Girls named 15 second-cholce occupational aspirations with teacher (11), nurse (5), and secretary (4) wost frequently chosen.

A slgniflcant relationship was found between sex-typing of flrstcholce ocoupational aspirations and the sex of the respondents. of 60 boys, 53 chose "traditional male" occupations, 3 "neutral" occupations: and only 1 a "female" occupation. This compares to the 60 girls" choices of 30 "female," 14 "male," and 9 "neutral" occupations. These findings 
support Schlossberg and Goodman's ${ }^{1}$ conclusion that children chose jobs for themselves that fall within the usual stereotypes. However, girls excluded themselves from "men's" jobs to a lesser degree than boys excluded themselves from "women's" jobs.

No significant differences in sex-typing of aspirations were found on the varlables of grade level and sociomeconomic status of the respondents.

The second part of the study investigated sex role expectations in children's perceptions of occupations. Significant differences were found on the variables of sex, grade level and soclo-economic status of respondents. Approximately half of the responses to the thirty occupatlons deplcted in the slide-tape serles indicated that occupations were seen as places where both a man and a woman could work. The results did indicate, however, that both boys and girls were more ready to exclude women from jobs than to exclude men from jobs. Girls, more than boys, did percelve women as being able to do the work in the occupations. These findings concur with those of Schlossberg and Goodman, ${ }^{2}$ wo also reported no appreciable increase in stereotyping from kindergarten to sixth grade.

In contrast, the present study found a decrease in the degree of stereotyping as the grade level of the respondents increased. A greater number of flfth-grade students, as compared to second graders and pre-

${ }^{1}$ Nancy Schlossberg and Jane Goodman, "A Woman's Place Children" Sex Stereotyping of Occupations, "Vocational Guldance Quarterly, XX (1972), 269 .

${ }^{2}$ Schlossberg and Coodman, p. 268. 
schoolers, saw both a man and a woman as belng able to perform the work of the occupations, although "man" was selected nore frequently than "woman."

Schlossberg and Goodman reported that sixth graders at model clty schools sterootyped more than those at middle income schools. ${ }^{1}$ Support for this conclusion can be wade on the basis of this study. Children attending middle to uppermidale elass sohools showed less sex-typins In their perceptions of occupations than children attending lower to lower-middle class schools.

\section{Conclusions}

Conclusions that can be drawn from the study can be summaxized as follows:

1. Children attending preschool, second grade, and fifth grade classes have a wide diversity of occupational aspirations. The number of occupations named by children differed on the variable of sex but not on the varlables of grade level and soclo-economic level.

2. Since preschool boys and girls named about the same number of different occupations as aspirations and second and flfth-grade boys named a greater number than did girls, it appears that the disparity occurs sowetlme between preschool and second grade.

3. The high frequency of single cholce aspirations may indicate that choices are fairly well crystallizod or that children nay not be aware of other vocational possibilities.

4. Boys reveal more sex-typing in thelr perceptions of occupa-

${ }^{1}$ Schlossbers and Coodman, p. 268 . 
tions than do girls, though a majority of boys and girls percelve that both a man and a woman could do the work in occupations.

5. Sex-typing in perceptions of occupations appears to decrease with increasing ages of children.

6. Children from lower to lower-middle class level schools appear to percelve more traditional sex role expectations than their middle to uppermiddle class counterparts in their perceptions of occupations.

7. While children may percelve both a man and woman as workers In an occupation, they tend to choose jobs for themselves that fall with in the usual stereotypes. This discrepancy between general perceptions and personalized choices seems especially characteristic of boys.

\section{Implications and Recomnendations}

The findings of the study have implications for parents and teachers of preschool and elementary school children. Support was found for the bellef that preschool years can be considered a bonallde stage in vocational development and awareness. Parents and teachers of preschool chlldren should be sure that young children have exposure to many occupations and role models, including workers in non-traditional sex roles. Children need to learn about occupations other than commity helpers. With increasing numbers of people working in technical jobs In large industries, especially in the area where the sample was dram, children may know where thelr parents work but st1ll have little understanding about what work the jobs entall. In 11ne with labor tronds. chllaren need to be encouraged to look at other than traditionally sexw 
typed occupations. This may be especially true for boys, who demonstrated even greater sex-typing in aspirations and perceptions of occupations than girls.

Career education may be having an influence on the reduction of sex role expectations in perceptions of occupations. The results of the study night reflect the effects of a cognitive career aducation program. The older children in the sample were less sex-typed in their responses. Children from lower soc10-economic levels especially need exposure to non traditional sex role models and opportuntities. Counselors and teachers should continue to provide opportunities for children to learn about a wide varlety of vocational opportunities in an environment where rapid changes are occurring in the world of work. Besldes encouraging perceptions of occupations as being open to both men and women, teachers, counselors, and parents should help chlldren personalize these nonstereotypic attitudes so that personal vocational aspirations reflect less sex-typing. Research should investigate the effects of career education on sex-typing of occupations.

Career education experiences should extend to young children and their parents. Parents could be helped to realize the 1mportance of encouraging children to viev occupations and the world of work as providing opportunties for both men and women to make meaningful contributions when they are not limited by sex role stereotypes.

Findings of the study suggest areas for further research. Replis cation of the study with other samples of children and with chlldren of different grade levels and soclo-econonic backgrounds would add to the knowledge about sex-typing in vocational aspirations and perceptions of 
occupations. Occupations other than the thirty represented in this study should be Included in future investigations of sex-typing. This study used a slide-tape series to assess perceptions. Alternative means might be devised to assess sex-typing of roles and occupations, especially with preschool children, whose attention span is limited, requiring a one-to-one relationship in interviews.

Developmental trends could be studied with longitudinal data, studying children from preschool years until they reach adulthood. Further research with preschool and elementary children could clarify the question about when sex-typing of aspirations and perceptions of occupations seem to crystallize. Data measuring sex-typing in attitudes before and after efforts to combat sexism should be collected about young children, including preschoolers.

Children need more exposure to the world of work. Teachers, parents, and employers should be sensitized to realize the importance of introducing children to non-stereotypic role models and vocational opportunities at a very young age. Inquirles into the vocational develope ment of children and adults should not neglect the aspect of sex role expectations. 
BIBLIOGRAPIY 


\section{BIBLTOGRAPHY}

\section{A. BOOKS}

Bardwick, Judith. ad. Readings on the Psychology of Women. New York Harpex and Row, 1972.

Boslooper. Thomas, and Marcla Hayes. The Fenininity Game. New York Stein and Day, 1973.

Chafetz, Janet Saltzman. Masculine, Feninine, or Human? Itasca, IIIInols: F. E. Peacock, 1974.

Enma Willard Task Force on Education. Sexism in Education. Minneapolls: Fima Willard Task Force on Education, 1973.

Frazier, Nancy, and Myra Sadker. Sexism in School and Soclety. Nev Yorks Harper and Row, 1973.

Freeman, Jo, ed. Women, A Feminist Perspective. Palo Alto, Callforala: Mayfield, 1975.

Genne, Ellzabeth S., and William H. Genne. Flrst of All Persons. Hev York: Friendship Press, 1973.

Corman, Anna M., and Louise Vetter. eds. Career Developent of Women. Proceedings of the 10th Anniversary Prograx. Columbus: The Centex for Vocational Education, Ohio State University, 1975.

Guilford, J. P. and Benjamin Fruchtor. Fundamental Statisties in Pyychology and Education. New York McGraw-H111, 1973.

Gysbers, Norman. ed. Developing Careers in the Elementary School. Columbus, Ohiot Charles E. Merrill, 1973.

Hoffman, M. L., and L. W. Hoffman. eds. Review of Child Development Research. Vol. I. Hartford, Russell Sage Foundation, 1964.

Hoppock, Robert. Occupetional Information. New York, MeGraw-Hi11, 1967.

Hoyt, Kenneth B., and others. Gareer Education: What It Is and How to Do It. Salt Lake Clty, Olympus, 1972.

Jandt, Fred E. The Process of Interpersonal Communication. San Franclsco Canf'ield Press, 1976.

McCandless, Boyd R., and Ellis D. Evans. Children and Youth Psychosoclal Development. HInsdale, Illinols: Dryden Press, 1973.

Maccoby, Eleanor, ed. The Development of Sex Differences. Stanford: Stanford Untversity Press, 1966. 
Mussen, Paul Henry, John Janeway Conger, and Jerome Kagan. Child Development and Personality. New York, Harper and Row, 1969.

Osipow, Samuel $\mathrm{H}$. Theorles of Career Development. New York, AppletonCentury-Crofts, 1973.

Phillips, John L., Jr. The Origins of Intellect, Plaget's Theory. 2d ed. San Francisco, W. H. Freeman and Company, 1975.

Roo, Ann. The Psychology of Occupations. New York John Wiley and Sons, 1956.

Seward, Georgene, and Robert C. Williamson. eds. Sex Roles in Changing Society. New York! Random House, 1970.

Sills, David. ed. Intermational Encyclopedia of the Social Sciences. Vols. VII, XIV. New York : Macmillan and The Free Press, 1968.

Smart, Mollie S., and Russell C. Smart. Children, Development and Relationships. New Yorkı Macmillan, 1972.

Snygg, Donald, and Arthur Combs. Individual Behavior. New York, Harper, 1959.

Somerville, Rose M. Introduction to Family Life and Sex Education. Bnglewood Cliffs, New Jersey, Prentice-Hall, 1972.

State of Iowa. Department of Public Instruction. Models for Career Education in Iowa. Des Moines, Iowa, Department of Public Instruction, 1973-1975.

Stone, L. Joseph, and Joseph Church. Chtldhood and Adolescence: A Psychology of the Growing Person. New York

U.S. Department of Labor. Bureau of Labor Statistics. Occupational Outlook Handbook. Washington, D.C.\& Govormment Printing office, 1994.

Wobster's New Collegiate Dictionary. Springfield, Massachusetts : G. and C. Mirrian, 1956.

Women on Words and Images. Help Wanted, Sexism in Career Education Materials. Princeton, New Jersey! Women on Words and Images, 1975.

\section{B. PERIODICALS}

Beumrind, Diana. "From Bach According to Her Abillty," School Review, LXXX (February, 1972), 161-197.

Bergmann, Barbara R., and Inva Adelman. "The 1973 Report of the President's Counc1l of Economic Advisers: The Economic Role of Women," The American Economic Rev1ew, LXIII (September, 1973), 509-514. 
Bernstein, Jean. "The Elementary School, Training Ground for Sex Role Stereotypes." Personnel and Guidance Joumal, LI (1972), 97-101.

Biller, Henry B. "Father Absence, Maternal Encouragement, and Sex Role Development in Kindergarten-Aged Boys," Chlld Development, XL (1969), $539-546$.

Bowman, Barbara T. "Role-Models and Social Change," Childhood Education, XLIX (January, 1973), 180-183.

Brook, Judith S., and others. "Aspiration Levels of and For Children: Age, Sex, Race, and Socloeconomic Correlates," Journal of Genetic Psychology, CXXIV (March, 1974), 3-16.

Brown, Daniel G. "Sex-Role Preference in Young Chlldren," Psychologlcal Monographs, LXX (14, Whole No. 421), 1956, 1-19.

"Sex-Role Preference in Young Children: Methodological Problems," Psychologlcal Reports, XI (1962), 477-478.

Carson, Mary. "Action in Cedar Rapids," Today's Education, LXIII (1974), 87.

Chasen, Barbara. "Sex-Role Stereotypling and Prekindergarten Teachers," Elementary School Journal, LXXIV (January, 1974), 220-225.

Choate, Roger. "Erod1ng Sex-Role Stereotypes," Tlmes Educational Supplement, May 12, 1972.

Conant, Margaret. "Learning to Be a Boy, a Girl, or a Person," PTA Magazine, LXVI (1972), 18-21.

Cooker, Philip G. "Vocational Values of Children in Grades Four, Flve, and Six," Elementary School Guidance and Counseling, VIII (December, 1973). 112-117.

"Bliminating Sexism in Schools and Educational Materlals." Library Journal. XCIX (Apr-11 15, 1974), 1171-1172.

Etaugh, Cla1re, Gene Collins, and Arlene Gerson. "Relnforcement of SexTyped Behaviors of Two-Year-0ld Children in a Nursery School Setting," Developmental Psychology. XI (1975), 255.

Frledland, Seymour J. "The Development of Role Concepts," Journal of Genet1c Psychology, CXXII (March, 1973), 81-88.

Gold, Allce R., and Carol St. Ange. "Development of Sex Role Stereotypes in Black and White Elementary School Girls," Developmental Psychology. $X(1974), 461$.

Goodson, Sylvia. "Chlldren Talk About Work," Personnel and Guidance Journal, XIIX (October, 1970), 131-136. 
Hahn, Carole. "The Me I Want to Be, Students" Aspirations in the Seventies," Social Education, XXXVIII (Apri1, 1974), 334-344.

Hall, Marjorle, and Robert A. Keith. "Sex Role Preference Among Children of Upper and Lower Social Class," Journal of Social Psychology, LXII (1964), 101-110.

Hartop, W. W. and E. A. Zook. "Sex Role Preference in Three- and FourYear-0ld Children," Journal of Consulting Psychology, XXIV (1960).
$420-426$.

Hedges, J. N. "Women at Work, Women Workers and Manpower Demands in the 1970 's," Monthly Labor Review, XCIII (1970), 19-34.

Hew1tt, Lymn Stewart. "Age and Sex Differences in the Vocational Aspirations of Elementary School Children," Journal of School Psychology. XCVI (1975). 173-177.

Howe, Florence. "Sexual Stereotypes Start Eaxly," Saturday Review, IIV (October, 1971), 76-82, 92-93.

Iglitzin, Lynne B. "A Child's-Eye View of Sex Roles," Today's Education, LXI (December, 1972), 23-25.

Jacklin, Carol Nagy, Eleanor E. Maccoby, and Anne E. Dick. "Barrier Behavior and Toy Preference, Sex Differences (And Their Absence) in the Year-Old Child," Child Development, XLIV (March, 1973), 196-200.

Jacobs, Carol, and Cynthia Eaton. "Sexism in the Elementary School," Today's Education, LXI (December, 1972), 20-22.

Joffe, Carole. "Sex Role Soclalization and the Nursery School: As the Twig is Bent," Journal of Marriage and the Family, XXXIII (August. 1971), $467-475$.

Johnson, Mirlam M. "Sex Role Learning in the Nuclear Fam1ly," Child Development, XXXIV (1963), 319-333.

Kagan, Jerome. "The Ch1ld's Sex Role Classification of School Objects," Ch1ld Development, XXXV (1964), 1051-1056.

- "The Emergence of Sex Differences," School Revieu, VIII (February, 1972), 217-227.

Lansky, L. M. , and G. McKay. "Sex Role Preference of KIndergarten Boys and Girls: Some Contradictory Results," Psychological Reports, XIII (1963), 415-421.

Letvitin, Teresa, and J. D. Chananie. "Response of Female Primary School Teachers to Sex-Typed Behaviors in Male and Female Children," Child Development. XLIII (December, 1972), 1309-1316. 
Levy, Betty. "Do Teachers Sell Girls Short?" Today's Education, LXI (December, 1972), 27-29.

Lewis, Michael. "Parents and Children: Sex Role Development," School Review, LXXX (February, 1972), 228-240.

Limmer, Eleanor. "What Are Little Girls Made Of?" Parents' Magazine, XLVII (February, 1972), 38-39, 62-64.

Looft, W. R. "Sex DAffexences in the Expression of Vocational Aspirations by Elementary School Children," Developmental Psychology. V (1971), 366.

- "Vocational Aspirations of Second-Grade Girls," Psychological Reports, XXVIII (1971), 28, 241-242.

Lynn, David B. "Sex-Role and Parental Identification," Ch1ld Development, XXXIII (1962), 555-564.

McClure, John W., and Gall T. McClure. "Cinderella Grows Up: Sex Stereotyping in the Schools," Educational Leadersh1p, XXX (October, 1972). 31-33.

May, Charles R., and M. Ebrahin Fakouri. "Taking a Second Look at Young Children's Sex Role Choices," Contemporary Education, XIV (Summer, 1974), 270-273.

Minuchin, Patricia. "The Schooling of Tomorrow's Children," School Review, LXXX (February, 1972), 199-216.

Mitchell, Edna. "The Learning of Sex Roles Through Toys and Books: A Woman's View," Young Children, XXVIII (1973), 226-231.

- "What About Career Education for Girls?" Educational Leadersh1p, XXX (December, 1972), 233-236.

Moglla, Ronald J., and Eugene C. Abraham. "Sex Roles in a Changing Society," Childhood Education, L (November, 1973), 115-117.

Neugarten, Bernice L. "Education and the Life-Cycle," School Review, LXXX (1972), 209-216.

O'Donne11, Holly Smlth. "Sexism in Language," Elementary English, L (October, 1973), 1067-1072.

O'Hara, Robert. "The Roots of Careers," Elementary School Journal, VI (February, 1962), 277-280.

Queen, Renee. "Genderation of the Self," Elementary English. LII (May, 1975). 717-720. 
Ross, Dorthea M., and She1la A. Ross. "Resistance by Preschool Boys to Sex In-Approprlate Behavior," Journal of Educational Psychology, LXIII (August, 1972), 342-346.

Saarlo, Terry N. Carol Nagy Jacklin, and Carol Kehr Tittle. "Sex Role Stereotyping in the Public Schools," Harvard Educational Review, KIIII (August, 1973), 386-416.

Sadker, Myra. "Are You Gullty of Teaching Sex Blas?" Instructor, LXXXII (August, 1972), 80-81.

Sadker, Myra, and David Sadker. "Sexism in Schools: An Issue for the $70^{\prime} \mathrm{s}, "$ Education Digest, XXXIX (Apr11, 1974), 58-61.

Schlossberg, Nancy K., and Jane Goodman. "A Woman's Place, Children's Sex Stereotyping of Occupations," Vocational Guidance Quarterly. $X X$ (1972), 266-270.

Sears, Robert R. "Relation of Early Socialization Experiences to SelfConcepts and Gender Role in Middle Childhood," Child Development. XLI (June, 1970), 267-289.

Super, Donald. "A Theory of Vocational Development," Amerlcan Psychologist. VIII (May, 1953), 185-190.

Swick, Kevin, and Mary Ellen Carlton. "An Examination of Occupational Interests of Kindergarten Children: Implications for Currlculum Development," Reading Improvement, XI (Spring, 1974), 58-61.

Tate, Janice M. "Sexual Blas in Sclence Fiction for Children," Elementary English, L (October, 1973), 1061-1064.

Thetford, Mary. "The Case for the Career Book in Grades Flve to Elght: A Feninist V1ew," Elementary English, L (October, 1973), 1059-1060. 1074.

Thompson, Jack M. "Career Development in the Elementary School: Ration ale and Implications for Elementary School Counselors, "The School Counselor, XVI (January, 1969), 208-210.

Thompson, Norman L., and Boyd R. McCandless. "IT Score Varlations by Instructional Style," Ch1ld Development, XLI (1970), 425-436.

Ward, W1111am D. "Process of Sex-Role Learning," Developmental Psychology: I (1969), 163-168.

Welsste1n, Naom1. "Woman as Nigger," Psychology Today, III (1969), 20-22. 58.

Weltzman, Lenore J. "Sex-Role Soclallzation in Plcture Books for Prew School Chlldren," American Journal of Soctology, LXXVII (May, 1972). $1125-1150$. 
Williams, John E., Susan M. Bennett, and Deborah L. Best. "Awareness and Expression of Sex Stereotypes in Young Children," Developmental Psychology, XI (1975), 635-642.

\section{THESES AND DISSERTATIONS}

Dohrmann, Rita Meade. "Children's Television Programming, A SexSocialization Agent." Unpublished Master's thesis, Drake University, 1974.

Fulton, Barbara. "Vocational Development of Chtldren." Unpublished Doctoral dissertation, University of Missourl, Columbia, 1971.

\section{DISSERTATION ABSTRACTS}

Atlas, John Wesley. "The Influence of Child-Rearing Practlces on the Self-Concept and Vocational Behavior of Middle and Lower-Class Children," Dissertation Abstracts International, XXXIV (1973). 563 A (Wayne State University).

Brady, Hobert Paul. "An Examination of Selected Variables Affecting the Vocational Development of Elementary School Children," Dissertation Abstracts International, XXXII (1972), 3681 A-3682 A (University of Cincinatt1).

Bucher, Carol Hope. "The Impact of a Non-Stereotyped Sex-Role Occupational Unit on Elementary School Children's Occupational Knowledge, Vocational Aspirations, and Expressed Occupational Att1tudes," Dissertation Abstracts International, XXXV (1974), 2672 A (University of Virginia).

Chaney, Reece. "Vocational Values of Children As They Relate to Economic Community, Grade Level, Sex and Parental Occupational Level," Dissertation Abstracts International, XXIX (1969), 2956 A-2957 A (Ohio University).

Harkness, Carol. "The Relative Impact of Identified Vocational Development Varlables on the Occupational Knowledge and Attitudes of Elementary School Children," Dissertation Abstracts International, XXXIV (1973). 566 A-567 A (University of Virginia).

Mulawka, Edward John. "Sex Role Typing in the Elementary School Classrook as Reinforcement of Sex Role Stereotypes Learned at Home, "Dlssertation Abstracts International, XXXIII (1973), 6472 A (Wayne State University).

Parker, James. "An Analysis of Children's Concepts of Selected Occupatlons," Dissertation Abstracts International, XXIV (1964), 3631-3632 (Northwestern University). 
Sisson, Lee Hansen. "Sex Role Interests and Social Competence in Young Children," Dissertation Abstracts International, XXXIV (1974), 4006 A (University of California-Los Angeles).

\section{E. ERIC REPORTS}

Burgette, Patricia Roop. Perceptions of Flfth and Sixth Grade Fernales of Vocational Goals and Expected Lifestyles. U.S., Educational Resources Information Center, ERIC Document ED $082068,1970$.

Hales, Lloyd W. , and Keith Yackee. Self-Concepts, Sex, and Work Values. U.S. Educational Resources Information Center, ERIC Document ED 090 459, April, 1974.

Kirchner, Elizabeth P., and Sarah I. Vondracek. What Do You Want to Be When You Grow Up? Vocational Choice in Children Aged Three to Slix. U.S., Educational Resources Information Center, ERTC Document ED 076 244, March, 1973.

Lee, Patrick C., and Gita Kedar. Sex Role and Pupil Role in Early Child hood. U.S., Educational Resources Information Center, BRTC Document ED $100491,1974$.

Montemayor, Raymond. Children's Performance on and Attraction to an Activity as a Function of Masculine, Feminine, or Neutral Labels on Sex-Role Preference. U.S., Educational Resources Information Center. ERIC Document ED 068 875, 1973.

Nadelman, Lorraine. Sex Identity in American Children: Memory, Knowledge. and Preference Tests. U.S., Educational Resources Information Center, ERIC Document ED 084 029, June, 1973.

Weeks, 0 'Neal. A New Look at Children's Sexuality and Sex Role Identification. U.S., Educational Resources Information Center, ERIC Document ED 097 992, Aprei1, 1974.

Women's Action Alliance. Sex-Stereotyping in Child Care, Non-Sexist Ch1ld Development Project. U.S., Educational Resources Information Center, ERIC Document ED $093476,1973$.

Zach, Lillian, and Michelle Price. The Teacher's Part in Sex Role Reinforcement. U.S. Educational Resources Information Center, BRTC Document ED $070513,1973$.

\section{F. OTHER SOURCES}

Cedar Falls Community Schools. "Career Education in the Elementary Schools," Cedar Falls, Cedar Falls Comnunity Schools, 1973. (Mimeographed). 
APPENDIX A

INFORMATTON NOTE FOR PARENTS 
INPORMATION NOTE FOR PAREMTS

Mrs. Mary Franken, an assistant professor of home economics at UNI, is completing her doctoral program at Drake University in Counsel Ing and Personnel Services. She has asked the cooperation of several educational facilities in our community in granting her permission to interviow young children to learn about how they perceive the world of work. She has explained the nature of her research to us, and we are pleased to be included in the statistical sample. During the last part of April she and a co-interviewer will hold twenty-minute interviews, using a silde serles, with some of the children from our school. 
APPENDIX B

IWTERVIEW PROCEDURE 
INTHRVIEW PROCEDURE

"H1! My name is "What's your name?" (Check to make sure it is on recording sheet.) "How old are you, ?"

"Do you know why I have asked you to come here today? (If child appears anxious, continue ice breaking, reflect on child's feelings. When at ease, proceed.)

"I asked you to come to visit with me today because I would like you to help me. I think your teacher told you that and $\mathrm{I}$ are here to talk with some children to learn about sone of their ideas about jobs and work that grown-ups do.

"You probably have thought about the work or job you would l1ke to do someday. What do you want to be when you grow up?" (Write down.)

"Have you another Idea about what you might want to do?" (Write down.)

"Today I would like to show you some plctures of places where people work. A volce on a tape will tell you about the work that would be done by a person who might work in the plcture. Some of these jobs have hard names. But if you will Iisten to what the tape tells you about the job. I think you w11l understand what a person on that job would do. The tape w1Il ask you a question after telling you about the job. It w11l ask you who could do the work of that job--a man, a woman, or both a woman and a man?"

"Let's look at a plcture and see what to do. This is a picture of a place where a tlcket taker might work. As you look at the plcture, think about who you think could do the work the tape tells you about. Let's 118ten..." (Turn on tape.)

"TIcket Taker. A ticket taker is a person who would take your ticket when you went into a game or a circus or a movie. Who could do the job of a ticket taker--a woman, a man, or both a woman and a man?"

"There aren"t any right or wrong answers--I only want to know who you think could do the work in that job. If you think only a woman could do that work, you would say 'woman.' If you think only a man could do that work, you would say "man." If you think both a woman and a man could do the work of a ticket taker, you would say "both." Try to decide if you think a man or a woman or both a man and a woman could do the work that the plcture and volce tell you about. But if you can't decide, you can tell me that you don't know, and we "11 go on to the next plcture. Do you have any questions? 
"Let's listen to the tape again and this time you can give me your answer." (Play tape and child responds.)

"Do you have any questions before we go on to more pictures?" (Pause) "Okay, let's go on." (Go through the 30 occupational slides with accompanying tape, stopping the tape whlle writing down chlld's response to each description. Then say:

"That was the last plcture. Thank you very much for your help, -" 
APPENDIX C

PROCEDURES FOR SELBCTIKG THE 30 OCCUPATIONS

REPRESENTED IN THE STUDY 


\section{DIRECTIONS TO JUDGES CATBGORIZIMG OCCUPATIONS}

Thank you for agreelng to help me as I work on my dissertation instrument. Sex roles are rapldly changing, and for my study I want to Investigate the degree to which children sex-type occupations. Therefore. I would like to categorize occupations into three categories--those considered traditionally for men, those considered traditionally for women, and those which are more neutral (less sex-typed).

I have selected sixty occupations from the U.S. Office of Educa= tion's fifteen occupational clusters that preschool and elementary school children could probably understand when shown a picture of the setting with accompanying explanatory audio tape.

Please sort the sixty cards into the three categories--occupations considered to be traditionally female, male, and neutral. You may select an occupation as neutral, not because equal number of nales and females have been enployed in that occupation, but on the basis that both men and women have $11 \mathrm{kely}$ been exployed in that occupation or because the occupation is less strongly sex-typed.

Please sort the cards, which are in alphabetical order, into the three categorles. When you have finalized your selections, please write the numbers of the cards you put into each category on the enclosed recording sheet. Then place this sheet in the envelope and seal it so that the respondents 1111 be anonymous. 
Table 17

Sixty Occupations frow the U.S. Office of Education Clusters Rated by 10 Judges into Categories of Traditionally Male, Traditionally Female, and Neutral

1. A1r Analyst

2. Air Traffic Controller

3. Artist

4. Attorney

5. Bakery Worker

6. Bookkeeper

7. Bulldozer Operator

8. Canp Counselor

9. Carpenter

10. Carpet Installer

11. Cartoonist

12. Coach

13. Computer Programmer

14. Cosmotologist

15. Dental Assistant

16. Dietician

17. Display Person/Window Dresser

18. Doctor

19. Elementary School Teacher

20. Farm Owner/Manager

21. Mahing Boat Operator

22. Floral Arranger

23. Forester

24. Grocery Cashler

25. Hotel Manager

26. Housekee per

27. Interlor Designer

28. Llbrarlan

29. Machine Tool Operator

30. Mall Carrler
31. Meteorologist

32. Motel Clerk

33. Nurse

34. Oceanographer

35. Organist

36. Park1ng Meter Attendant

37. Performer

38. Pet Shop owner

39. Physical Therapist

40. P1lot

41. Polltician

42. Postal Clerk

43. Professional Athlete

44. Proofreader

45. Receptionist

46. Reservation Agent

47. Salesperson

48. Secretary

49. Sewing Machine Operator

50. Short Order Cook

51. Snow Renover

52. Soclal Worker

53. Telephone Operator

54. Television Announcer

55. Tleket Taker

56. Travel Agent

57. Tropical Fysh Dealer

58. Truck Driver

59. Upholsterex

60 . Nedding Consultant 
Table 18

Occupations Selected for the Study from the 15 U.S. Office of Education Career

Clusters with Proportion of Rater Agreement for Assignment to

Male, Fenale, or Neutral Category by 10 Raters

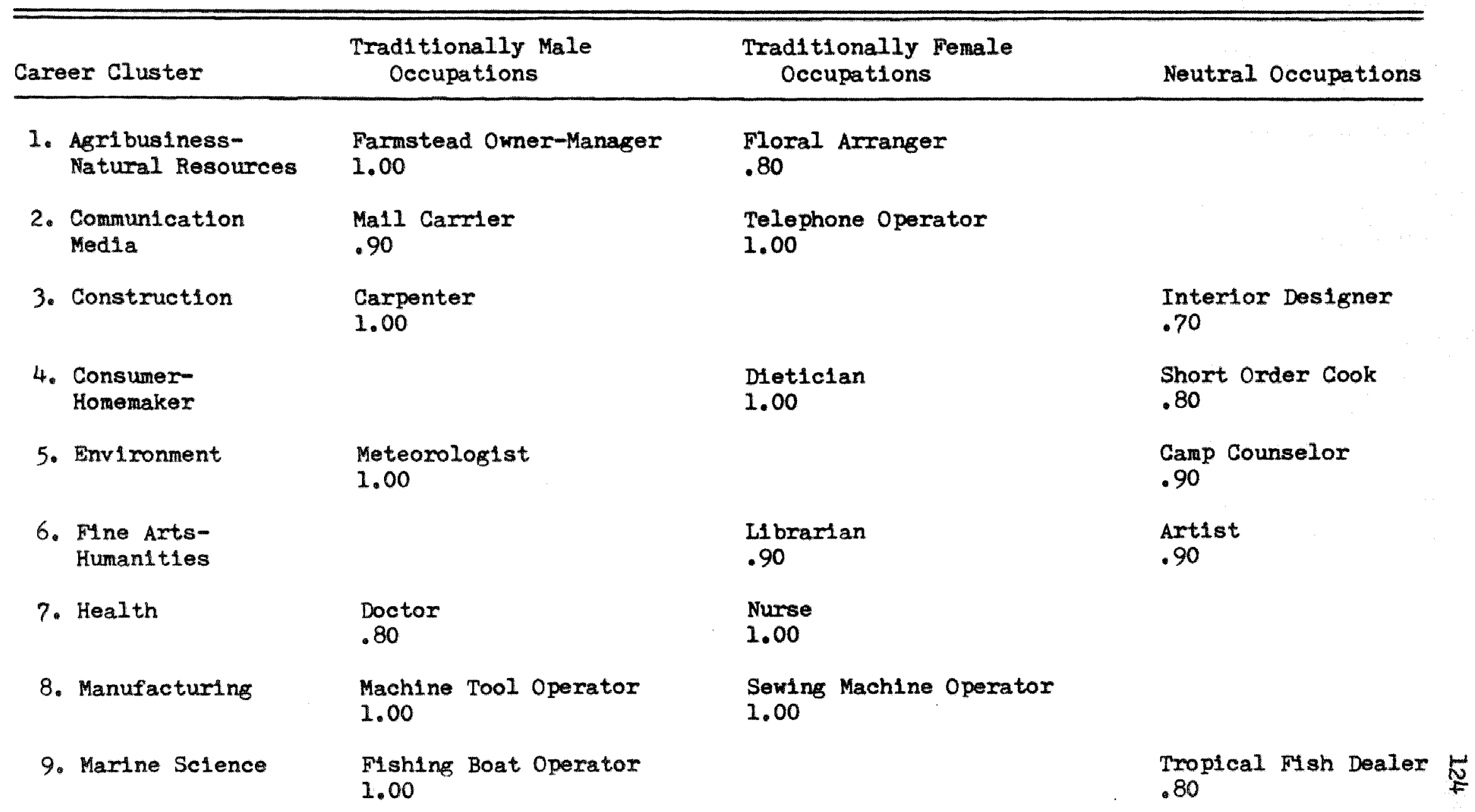


Table 18 (Continued)

\begin{tabular}{|c|c|c|c|}
\hline Career Cluster & $\begin{array}{l}\text { Traditionally Male } \\
\text { Occupations }\end{array}$ & $\begin{array}{c}\text { Traditionally Female } \\
\text { Occupations }\end{array}$ & Neutral Occupations \\
\hline $\begin{array}{l}\text { 10. Marketing and } \\
\text { Distribution }\end{array}$ & & $\begin{array}{l}\text { Grocery Store Cashier } \\
.90\end{array}$ & $\begin{array}{l}\text { Salesperson } \\
.90\end{array}$ \\
\hline 11. Office & & $\begin{array}{l}\text { Secretary } \\
1.00\end{array}$ & $\begin{array}{l}\text { Computer Programmer } \\
.70\end{array}$ \\
\hline 12. Personal Services & & $\begin{array}{l}\text { Cosmotologist } \\
1.00\end{array}$ & $\begin{array}{l}\text { Pet Shop Manager } \\
.70\end{array}$ \\
\hline 13. Public Service & $\begin{array}{l}\text { Politician } \\
.90\end{array}$ & $\begin{array}{l}\text { Elementary Teacher } \\
.90\end{array}$ & \\
\hline $\begin{array}{l}\text { 14. Recreation and } \\
\text { Hospitallty }\end{array}$ & $\begin{array}{l}\text { Coach } \\
.80\end{array}$ & & $\begin{array}{l}\text { Motel Clerk } \\
.80\end{array}$ \\
\hline 15. Transportation & $\begin{array}{l}\text { Truck Driver } \\
1.00\end{array}$ & & $\begin{array}{l}\text { Travel Agent } \\
1.00\end{array}$ \\
\hline
\end{tabular}


APFENDIX D

SCRIPT OF THE SLIDE-TAPE PRESENTATION 
TAPE SCRIPT

Sample Description to Accompany Sample Slide (recorded twice),

Ticket Taker. A ticket taker is a person who would take your ticket when you went into a game or a circus or a movie. Who could do the job of a ticket taker-a woman, a man, or both a woman and a man?

Descriptions to Accompany Slides 1-30,

1. Artist. This plcture shows a drawing board where an artist could work. An artist could work in different ways, 11ke drawing. painting, or working with pictures in a magazine or book. Who could do the work of an artist--a woman, a man, or both a woman and a man?

2. Camp Counselor. A camp counselor helps children who go to summer camp. A counselor swims and plays with campers and helps them with any problems they have. A camp counselor works outdoors a lot of the time. Who could do the work of a camp counselor-a man, a woman, or both a man and a woman?

3. Carpenter. A carpenter uses tools 11ke a hammer and a saw to put up a building like the one you see in this picture. A carpenter does a lot of work with wood and nalls. Who could do the work of a carpenter-a man, a woman, or both a man and a woman?

4. Coach. A coach helps people who play sports and games. This plcture shows a locker room where players leave their clothes when they are in the gym or outside. A coach may help one person at a time or a tean play a game better. Who could do the work of a coach--a man, a woman, or both a man and a woman?

5. Computer Programer. You may have heard people talk about computers. Conputers are speclal machines like the one you see here. A computer programner is a worker who is needed to plan the way information is put into the computer so the numbers come out making sense. Who could do the work of a conputer programmer-a man, a woman, or both a man and a woman?

6. Cosmotologist. A cosmotologist is also called a beauty operator or halr dresser. Beauty operators work in a beauty shop. They wash, cut, and comb halr, and give permanents. Who could do the work of a cosmotologist or beauty operator-a woman, a man, or both a woman and a man?

7. Dietlclan. A dieticlan is a person who knows the kinds of foods that people need to eat to be healthy and strong. Dieticlans plan the kinds of food that cooks make for hot lunch or for people on 
a special diet. A dietician has planned the food you see in this picture. Who could do the work of a dietician--a woman, a man, or both a woman and a man?

8. Doctor. A doctor takes care of people when they are sick or hurt. A doctor also uses a stethescope and a thermometer when giving check-ups to make sure people are in good health. Who could do the work of a doctor-a man, a woman, or both a man and a woman?

9. Elementary Teacher. A school room is where an elementary teacher helps boys and girls learn to read, wrlte, do their numbers and learm about people and the world they live in. Who could do the work of an elementary teacher--a man, a woman, or both a man and a woman?

10. Farm Owner/Manager. A farm owner's job is to plan how to use land and money and machinery so that they can grow crops and raise animals. This gives people the food they buy in stores. Who could do the work of a farm owner/manager-a man, a woman, or both a man and a woman?

11. Flshing Boat Operator. Fishing is another way people get food. A person who runs a fishing boat takes the ship or boat out to sea and uses nets or traps to catch flsh and lobsters to sell to stores and restaurants. Who could do the work of a flishing boat operator - -a man, a woman, or both a man and a woman?

12. Floral Arranger. A flower shop is where a floral arranger works to make pretty bouquets and corsages of flovers. People order flowers to send people when they are sick and for weddings or speclal times durling the year. Who could do the work of a floral arranger-a woman, a man, or both a woman and a man?

13. Grocery Store Cashler. Using a cash register is the job of a grocery store cashler. The cashler punches the amount each thing costs, gives the rlght change to the customer, and sacks up the groceries. Who could do the work of a grocery store cashler-a woman, a man, or both a woman and a man?

14. Interlor Deslener. This room shows pieces of carpet and material that an interlor designer would use when planning the colors and furntture and curtains for the inside of a house or building. Interlor designers work with people to help them think about what they like and need in the rooms where they live or work. Then they find the furniture, carpet, and plctures that make the room look nice. Who could do the work of an interior designer--a man, a woman, or both a man and a woman?

15. Librarian. A librarian may work in a clty library, a school IIbrary, or a spectal place like a law 11 brary. Choosing books and materials for the library and helping people find books and 
information they need are important work of a 11 brarlan. Who could do the work of a librarian--a man, a woman, or both a man
and a woman?

16. Machine Tool Operator. This plcture shows a machine used by a machine tool operator. Metal parts for engines and machines are made on a lathe, a drill press, or a grinding machine. Who could do the work of a machine tool operator--a woman, a man, or both a woman and a man?

17. Mail Carrier. A mall carrier drives a small truck or walks a certain route to deliver mail and pick up mall. Carriers first sort the mail at the post office and then go on their way to homes and business places. Who could do the work of a mall carrier-a woman, a man, or both a woman and a man?

18. Meteorologist. A meteorologist uses instruments like the ones here to study the weather. The air, the wind, and how much water is in the air are measured to help tell the kind of weather to expect. Then the weather report is given on the radio and television. Who could do the work of a meteorologist or weather forecaster--a woman, a man, or both a woman and a man?

19. Motel Clerk. A motel clerk's job is to rent rooms to people when they come to stay at a motel. A motel clerk makes reservations for people who call ahead to save them a room. Then the motel clerk checks them in and gives them a key when they get there. Who could do the work of a motel clerk--a man, a woman, or both a man and a woman?

20. Nurse. This picture shows a nursing desk at a hospital. Nurses also work in a doctor's office or even a school. A nurse follows a doctor's orders by taking care of patients, giving them medicines they need, and watching how they get along when they are sick. Who could do the work of a nurse--a woman, a man, or both a woman and a man?

21. Pet Store Manager. Many kinds of animals are found in pet stores. The manager of a pet store chooses the many kinds of animals and pet supplies sold in the store. A manager may hire other workers to take care of the pets and to sell the things in the store. Who could do the work of a pet store manager--a woman, a man, or both a woman and a man?

22. Politician. A politician is a person who runs in an election to work in the city or state or United States government. State politicians work in the State Capitol Building. Here at the capitol they write laws, vote on laws, make speeches, and get letters from the people who voted for them. Who could do the work of a politician -a woman, a man, or both a woman and a man? 
23. Salesperson. A salesperson may work in a store selling clothes, insurance, furntture, cars, or many other things. A salesworker should try to be helpful to customers. Who could do the work of a salesperson--a woman, a man, or both a woman and a man?

24. Secretary. Secretarles work in offices, and they type letters and reports. They use office machines, keep papers filed, and talk to the people who call or cone into the office. This plcture shows a secretary's desk, typewriter, and places for filing things. Who could do the work of a secretary--a man, a woman, or both a man and a wowan?

25. Sewing Machine Operator. A sewing machine operator uses a sewing machine that is heavier and runs faster than a sewing machine found in a home. Sewing machine operators sew clothes, curtains, and many other things people buy in a store. Who could do the work of a sewing machine operator--a man, a woman, or both a man and a woman?

26. Short Order Cook. This is a large kitchen where a short order cook makes sandwiches and meals that people order in a restaurant. A cook makes the food so that it looks and tastes good. Who could do the work of a short order cook--a woman, a man, or both a woman and a man?

27. Telephone Operator. A telephone operator works at a place like you see here to help people w1th their telephone calls. The operator may help a person make a call, find a number, or tell a caller how much a call costs. Who could do the work of a telephone operator-a man, a wowan, or both a man and a woman?

28. Travel Agent. A travel agent helps people learn about places to visit and ways to get there. A travel agent may help a person plan a vacation or a trip and make the reservations for a plane or train as well as for a place to stay. Who could do the work of a travel agent--a woman, a man, or both a woman and a man?

29. Tropical Fish Dealer. Tropical flsh dealers raise and sell the interesting tropical fish people buy for their aquarluns. Tropical fish dealers may have their business in their homes or in special shops. They also sell fish food and tanks needed to raise tropical fish. Who could do the work of a troplcal fish dealer-a man, a woman, or both a man and a woman?

30. Truck Driver. Trucks carry many things all over the country. A truck driver is responsible for whatever is in the truck during the trip to where $1 t$ w1ll be delivered. Whether the truck is a large one or a smaller one, a truck driver must be a very good drlver. Who could do the work of a truck driver--a woman, a man, or both a woman and a man? 